\title{
Eukaryotic protein glycosylation: a primer for histochemists and cell biologists
}

\author{
Anthony Corfield ${ }^{1}(\mathbb{C}$
}

Accepted: 25 November 2016 / Published online: 23 December 2016

(C) The Author(s) 2016. This article is published with open access at Springerlink.com

\begin{abstract}
Proteins undergo co- and posttranslational modifications, and their glycosylation is the most frequent and structurally variegated type. Histochemically, the detection of glycan presence has first been performed by stains. The availability of carbohydrate-specific tools (lectins, monoclonal antibodies) has revolutionized glycophenotyping, allowing monitoring of distinct structures. The different types of protein glycosylation in Eukaryotes are described. Following this educational survey, examples where known biological function is related to the glycan structures carried by proteins are given. In particular, mucins and their glycosylation patterns are considered as instructive proofof-principle case. The tissue and cellular location of glycoprotein biosynthesis and metabolism is reviewed, with attention to new findings in goblet cells. Finally, protein glycosylation in disease is documented, with selected examples, where aberrant glycan expression impacts on normal function to let disease pathology become manifest. The histological applications adopted in these studies are emphasized throughout the text.
\end{abstract}

Keywords Eukaryocyte - Glycans · Glycoprotein · Glycosylation $\cdot$ Histochemistry $\cdot$ Mucin

\section{Introduction}

Histochemists and cell biologists are familiar with the ubiquitous presence of glycans. In view of the increasing

Anthony Corfield

corfielda@gmail.com

1 Mucin Research Group, School of Clinical Sciences, Bristol Royal Infirmary, University of Bristol, Bristol BS2 8HW, UK awareness that their structure is an ideal platform to store information [Winterburn and Phelps 1972; Gabius 2009, 2015; please see also the introduction to this theme issue (Gabius and Roth 2017)], a survey of their characteristics is timely. In connection with the overview on glycolipids (Kopitz 2017, this issue), an introduction to protein glycosylation is provided here. Present in archae- and eubacteria and in Eukaryotes (Reuter and Gabius 1999; Patsos and Corfield 2009; Wilson et al. 2009; Zuber and Roth 2009; Corfield 2015; Corfield and Berry 2015; Tan et al. 2015), protein glycosylation is shared by organisms of all three urkingdoms, associated with diseases when aberrant (Hennet 2009; Hennet and Cabalzar 2015). Starting with structural aspects, functional implications are then exemplarily discussed.

\section{Glycosylation of proteins: general aspects}

Most of the proteins are subject to glycosylation by a wide variety of enzymatic mechanisms. The length of the conjugated glycan ranges from a single sugar moiety to branched structures and the long glycosaminoglycan chains (Fig. 1; for information on proteoglycans, please see Buddecke 2009).

This wide spectrum of structural modes of glycosylation requires access to detailed information available on the presence of glycans. Representative techniques are listed as follows:

- Detection of glycans as carbohydrates in glycoproteins using chemical assays. This can be applied for screening in standard fractionation techniques such as highperformance liquid chromatography, size fractionation chromatography, ion-exchange chromatography, elec- 


\section{Box 1 | Major classes of vertebrate glycan structures}

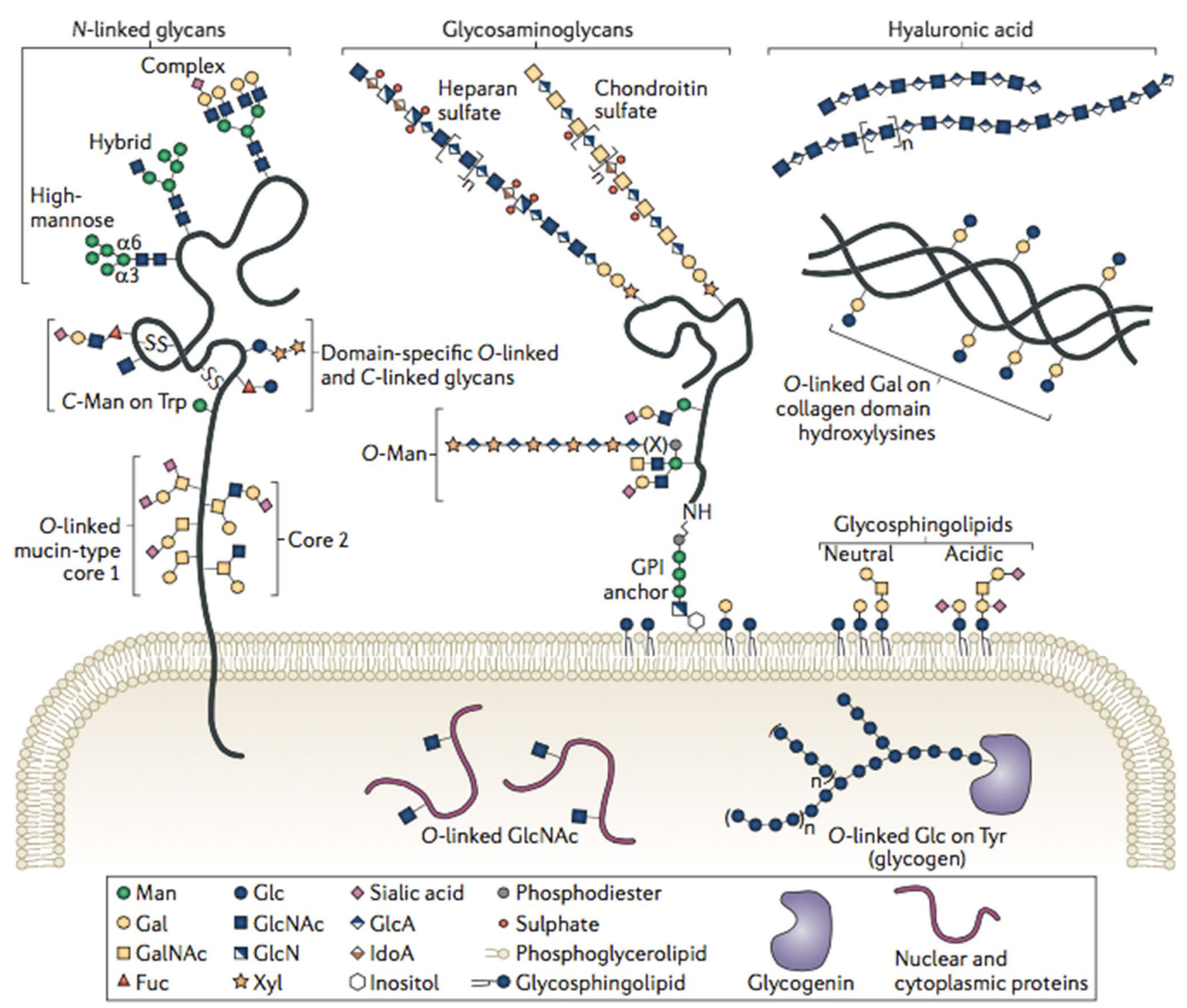

Fig. 1 Classes of vertebrate glycan structures. Membrane and secreted proteins have $N$-glycan, GlcNAc to asparagine as oligomannose, complex or hybrid forms, or $O$-glycans linked through GalNAc to serine/threonine with eight core structures and extension. Glycosaminoglycans have a core linkage tetrasaccharide to protein, with subsequent disaccharide repeats and characteristic sulphation patterns. They may be secreted, transmembrane or GPI-anchored. Hyaluronan is not linked to a protein. $O$-Mannosyl residues may be extended.
$O$-Glucose and $O$-fucose are found in EGF domains of some proteins. $\mathrm{C}$-Mannose is attached to protein tryptophan side chains. Single $\beta-O$ GlcNAc is found on many cytosolic and nuclear proteins. The collagen disaccharide is linked to hydroxylysine and through galactose. Glycogen is linked through glucose unit to a tyrosine in glycogenin. Glycosphingolipids contain glycans linked to a ceramide carrier; from Moremen et al. (2012), with permission

of $O$-acetylated sialic acids in human colon using the mild-PAS method, please see Fig. 2).

- Detection of glycan by probes with specificity to glycans, i.e. monoclonal antibodies (such as the CD-based reagents specific for the T/Tn antigens; for an overview, please see Gabius et al. 2015) or lectins (for an introduction to lectins and their application in cyto- and histochemistry, please see Kaltner et al. 2017; Manning et al. 2017, this issue). Working with cytological 


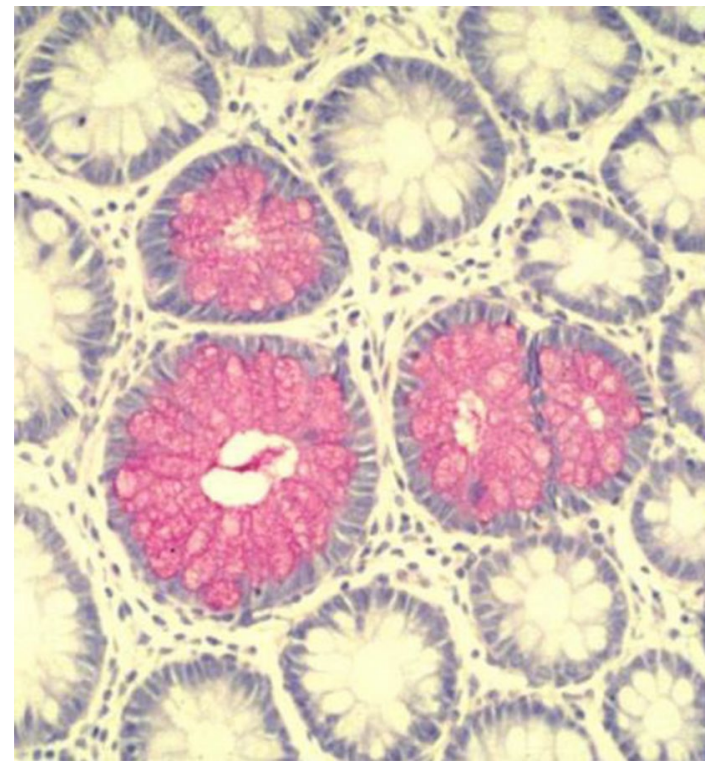

Fig. 2 mPAS detection of sialic acids in human colon. Mucus stored in goblet cell thecae. Staining of the colonic mucosa with the mild periodic acid-Schiff reaction stains non- $O$-acetylated sialic acids and demonstrates the location of the mucus prior to secretion; from Corfield (2011), with permission

specimen or tissue sections, glycophenotyping is readily feasible with labelled lectins by various microscopical techniques (Roth 1993, 1996, 2011; Habermann et al. 2011). Using chemically prepared compounds as inhibitors (Murphy et al. 2013; Roy et al. 2016), structural and topological aspects of the specificity of lectin binding can be analysed (André et al. 2016; Roy et al. 2017 , this issue). In addition to their application, lectins have found a broad range of applications for glycoprotein analysis (for compilation, please see Table 1 in Solís et al. 2015). These versatile assays also shape the notion that such interplay will have physiological relevance (for information on tissue lectins, please see Gabius et al. 2016; Kaltner et al. 2017; Manning et al. 2017; Mayer et al. 2017; Roth and Zuber 2017, this issue).

\section{Glycosylation: biological roles}

Glycosylation is a flexible co- and posttranslational modification that has been adopted by Eukaryotes to create a dynamic strategy applicable in modern biology. As many options are possible, an overview of the biological relevance of glycan chains in glycoproteins is shown in Fig. 3.

Backed by exemplary references, special aspects are highlighted:

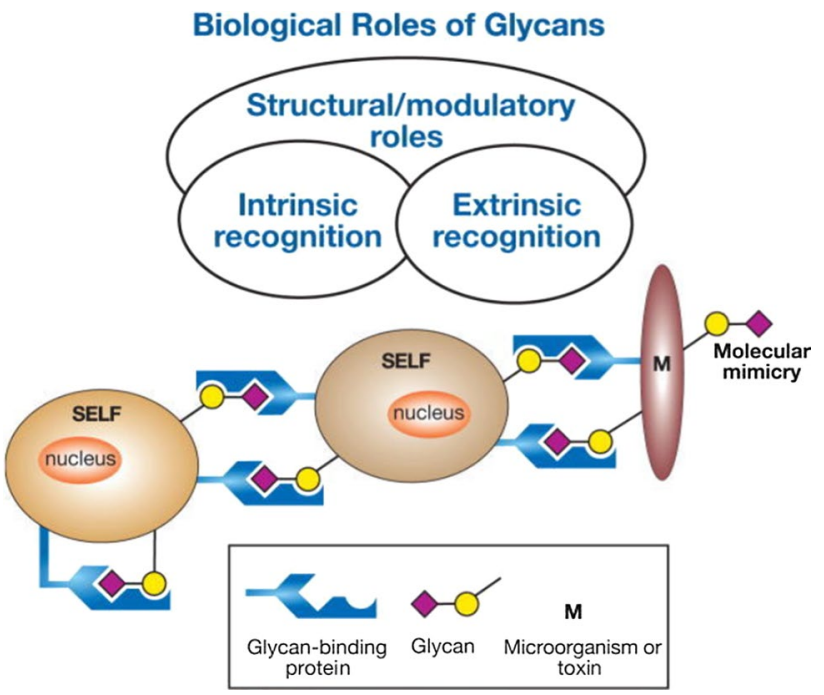

Fig. 3 Biological roles of glycans. A general classification of the biological roles of glycans is presented, emphasizing the roles of organism proteins in the recognition of glycans; from Varki and Lowe (2009), with permission

- Impact on the physicochemical properties of the glycoprotein molecule. The secreted mucins are an example, where viscoelasticity and gel formation establish a protective barrier on mucosal surfaces (Newton et al. 2000; Pearson et al. 2000; Atuma et al. 2001; Allen and Flemström 2005; Gustafsson et al. 2012; Johansson and Hansson 2012; Verdugo 2012; Berry et al. 2013; Birchenough et al. 2015).

- Docking sites for tissue lectins, hereby serving a broad range of functions including adhesion, growth regulation or routing (for further information, please see Gabius et al. 2011, 2016 and in this issue, Kaltner et al. 2017; Manning et al. 2017; Mayer et al. 2017; Roth and Zuber 2017). The quality control and the specific delivery of glycoproteins in tissues and cells are illustrative examples. Specific functions of individual glycoproteins are related to their location and selective expression. The glycans serve as postal code for routing and delivery, for example for asialoglycoproteins, lysosomal enzymes carrying mannose-6-phosphate or glycoproteins in galectin-dependent apical/axonal transport (Kornfeld et al. 1982; Stechly et al. 2009; Velasco et al. 2013; Higuero et al. 2017; Manning et al. 2017, this issue).

In order to illustrate the importance and scope of protein glycosylation it is necessary to enumerate the range glycan structures that have been identified and which are carried by glycoproteins. Table 1 gives an overview of the broad scope of glycan structures found in Eukaryotes. The main 
Table 1 Main types of glycan structures

\begin{tabular}{|c|c|}
\hline Glycan Group & Glycan Structure \\
\hline Proteoglycans & 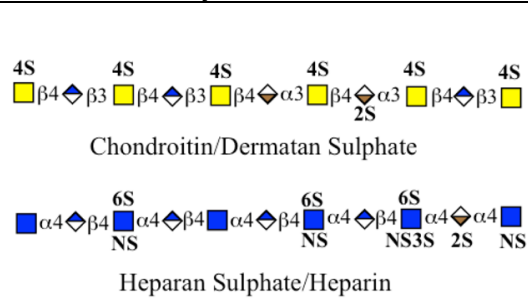 \\
\hline Hyaluronan & $\square \beta 4 \diamond \beta 3 \square \beta 4 \diamond \beta$ \\
\hline $\begin{array}{l}\text { Glycoproteins } \\
\text { N-Glycans }\end{array}$ & 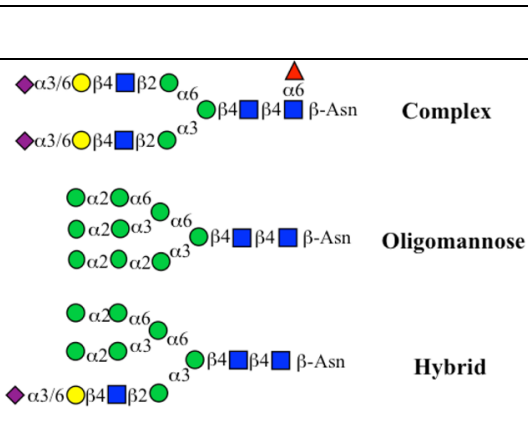 \\
\hline $\begin{array}{c}\text { Glycoproteins } \\
\text { O-Glycans }\end{array}$ & 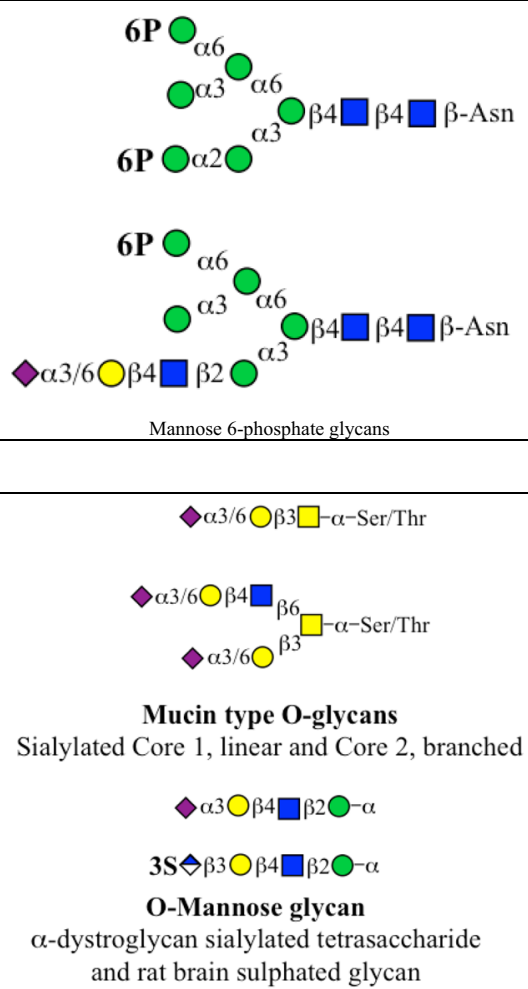 \\
\hline
\end{tabular}

types of glycosylation are $\mathrm{N}$-linked and $O$-linked glycans, with a considerably smaller group of C-linked glycans.

$N$-Linked glycans are attached through an $N$-glycosidic bond between asparagine and $\beta$ - $N$-acetyl-D-glucosamine $(\mathrm{GlcNAc})$. The asparagine residues are associated with the
Table 1 continued

\begin{tabular}{|c|c|}
\hline & $\begin{array}{c}\diamond \alpha 3 / 6 \bigcirc \beta 4 \square \beta 3 \triangle \alpha-\mathrm{Ser} / \mathrm{Thr} \\
\text { Notch O-Fucose tetrasaccharide } \\
\text { EGF-like repeat } \\
\qquad \alpha 3 \downarrow \alpha 3 \bigcirc-\alpha-\mathrm{Ser} / \mathrm{Thr} \\
\text { Notch O-Glucose trisaccharide } \\
\text { EGF-like repeat } \\
\text { O } \alpha 2 \bigcirc-\beta \text {-Hyl/Hyp } \\
\text { Collagen O-Galactose disaccharide }\end{array}$ \\
\hline $\begin{array}{c}\text { Glycoproteins } \\
\text { O-GlcNAcylation } \\
\end{array}$ & $\square-\beta-$ ser/thr \\
\hline $\begin{array}{c}\text { Glycoproteins } \\
\text { Glycophosphatidylinositol } \\
\text { (GPI) anchor }\end{array}$ & \\
\hline & 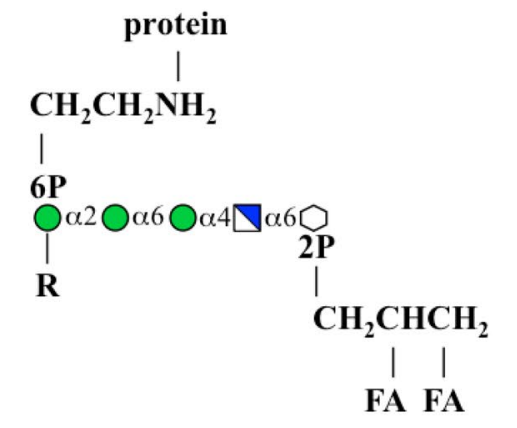 \\
\hline $\begin{array}{l}\text { Glycoproteins } \\
\text { C-Mannose }\end{array}$ & O- $\alpha$-Tryp \\
\hline \multirow[t]{2}{*}{ Glycosphingolipids } & \\
\hline & $\begin{array}{c}\bigcirc \beta 3 \square \beta 4 \bigcirc \beta 4 \bigcirc-\beta \mathrm{Cer} \\
\text { Neutral glycosphingolipid GA1 } \\
\text { Acidic glycosphingolipid GT1a }\end{array}$ \\
\hline
\end{tabular}

Major groups of eukaryotic glycans. Examples of the general types of glycan, largely drawn from animal examples, are shown. Key: yellow circles, D-galactose; yellow squares, $N$-acetyl-D-galactosamine; blue circles, D-glucose; blue squares, $N$-acetyl-D-glucosamine; blue/white squares, D-glucosamine; green circles, D-mannose; red triangles, L-fucose; purple diamonds, $N$-acetyl-D-neuraminic acid; light blue diamonds, $N$-glycolyl-D-neuraminic acid; blue/white diamonds D-glucuronic acid; orange/white diamonds, L-iduronic acid; orange stars, D-xylose; white diamonds, myo-inositol. All glycosidic linkages are shown as $\alpha$ or $\beta$, with the corresponding position; for example, $\beta 4, \beta 1,4$ linkage. $2 S$ 2- $O$-sulphate, $3 S$ 3- $O$-sulphate, $4 S$ 4- $O$-sulphate, $6 S$ 6-O-sulphate, $2 P$ 2-O-phosphate, $6 P$ 6-O-phosphate, $A s n$ asparagine, $\mathrm{CH}_{2} \mathrm{CH}_{2} \mathrm{NH}_{2}$ ethanol amine, $\mathrm{FA}$ fatty acid, predominantly palmitate, $H y d$ hydroxylysine, Hyp hydroxyproline, $N S N$-sulphate, Tryp tryptophan, $R$ various glycan substitutions occur at the initial mannose in GPI anchors; from Corfield and Berry (2015), with permission 
recognition sequence Asn-X-Ser/Thr. This sequence and the associated synthetic pathway are conserved in evolution for all of the metazoan (Aebi 2013; Breitling and Aebi 2013). The $N$-glycans contain a common, branched core comprising Man $\alpha 1,6(\operatorname{Man} \alpha 1,3) \operatorname{Man} \beta 1,4 \mathrm{Glc} N A c \beta 1,4 \mathrm{Glc} N A c \beta 1-$ Asn-X-Ser/Thr and this is extended to yield three different types, oligomannose, complex and hybrid (Zuber and Roth 1990). Common features occur in the extension of the $N$-glycan core, generation of two antennae from the $\operatorname{Man} \alpha 1,6(\operatorname{Man} \alpha 1,3) \operatorname{Man} \beta 1,4 \mathrm{Glc} N A c \beta 1,4 \mathrm{Glc} N A c \beta 1$ Asn$\mathrm{X}$-Ser/Thr core. Second, the core is extended to yield oligomannose forms containing only mannose, formation of complex types having antennae terminated with a sialylated $\mathrm{N}$-acetyllactosamine trisaccharide, plus a fucose on the internal GlcNAc linked to the asparagine and finally hybrid types containing both oligomannose linked to Man $\alpha 1,6$ and complex units attached to the Man $\alpha 1,3$ residues (Aebi 2013; Breitling and Aebi 2013).

The process of $\mathrm{N}$-glycosylation, starting co-translationally, is common across the Eukaryotes in accordance with their comprehensive range of biological functions. The enzymes responsible for the stepwise generation of the precursor glycan utilize a dolichol pyrophosphate lipid carrier and follow a series of trimming and processing steps that are conserved across the Eukaryotes. A series of three cytoplasmic glycosyltransferases, initially a GlcNAc transferase followed by mannosyltransferases, result in the formation of the Man5GlcNAc2 pentasaccharide. Subsequent extension occurs in the lumen of the endoplasmatic reticulum and the dolichol-oligosaccharide is translocated by a flippase. In the ER lumen a series of manipulations occur to generate the range of $\mathrm{N}$-glycans required for the tissue (Zuber and Roth 2009; Aebi 2013; Breitling and Aebi 2013).

Oligosaccharyltransferase (OST) is the principal enzyme in the $N$-glycan pathway. It catalyses the transfer of the glycan from the dolichol phosphate-oligosaccharide to an asparagine in Asn-X-Ser/Thr motifs on acceptor polypeptides. OST is a hetero-oligomeric complex comprising 8 subunits in most Eukaryotes. The transfer reaction catalysed by OST is exclusive, showing strict substrate specificity applicable to wide range of protein acceptors (Zuber and Roth 2009; Aebi 2013; Breitling and Aebi 2013).

$\mathrm{N}$-Glycosylation is closely linked with important glycoprotein regulatory events. Protein folding is mediated by the chaperones calnexin and calreticulin and ensures that glycoproteins that exit the ER are correctly folded (Roth 2002). Trimming of the terminal triglucosyl unit by $\alpha$-glucosidases I and II is followed my monitoring of the glycoprotein. In the case that folding is incomplete a single $\alpha$-glucose residue is transferred to the $\alpha 1,2$ mannose unit on the $\alpha 1,3$ mannosyl antenna. Recycling ensues and the glycoprotein is reassessed in the same manner. Those glycoproteins that do not fold properly are eliminated by ER-associated degradation (Roth 2002; Aebi 2013; Breitling and Aebi 2013; Roth and Zuber 2017).

The second most common type of glycosylation, the $O$-glycosidic linkage coupling serine or threonine to $\alpha-N$ acetyl-D-galactosamine ( $\mathrm{GalNAc}$ ), also known as mucintype glycosylation, as it is the major glycosylation found in this large group of heavily glycosylated proteins (Corfield 2015). Other non-mucin-type $O$-glycans have been detected, and these are described later. The $O$-glycans present in mucins are located in variable number tandem repeat domains, which vary in size and sequence between the different mucins (Hattrup and Gendler 2008; Thornton et al. 2008; Bafna et al. 2010; Kreda et al. 2012; Corfield 2015). $O$-Glycans do not have a peptide recognition sequon, as established for $\mathrm{N}$-glycans, but are characterized by eight different core structures, as shown in Table 2 . The most frequently observed are cores 1, 2, 3 and 4 .

The initial transfer of a GalNAc to serine and threonine residues in proteins is catalysed by a family of GalNAc transferases (Patsos and Corfield 2009; Tabak 2010; Gerken et al. 2011; Bennett et al. 2012; Gerken et al. 2013; Revoredo et al. 2016), the site of action localized immunohistochemically by electron microscopy (Roth et al. 1994). The core structures are extended through $N$-acetyllactosamine backbone repeat unit of type 1 (Gal $\beta 1,3 \mathrm{GlcNAc-})$ or type 2 (Gal $\beta 1,4 \mathrm{Glc} N A \mathrm{c}-)$ or the blood group antigens I (Gal $\beta 1,3 \mathrm{GlcNAc} \beta 1,3(\mathrm{GlcNAc} \beta 1,6) \mathrm{Gal} \beta 1,4-)$ and I (Gal $\beta 1,4$ GlcNAc $\beta 1,3$ Gal $\beta 1,4-R)$. Peripheral glycosylation of these structures is extensive and includes $\mathrm{ABO}$ and Lewis blood groups together with sialylated, fucosylated and sulphated glycans. The pathways responsible for the biosynthesis of these glycans are well studied (Schachter and Brockhausen 1992; Brockhausen and Schachter 1997; Patsos and Corfield 2009; Corfield 2015; Corfield and Berry 2015). Unique for mucin glycosylation is the $\alpha$-GlcNAc terminus of core $2 \mathrm{O}$-glycans in the gastrointestinal tract, which is readily detectable with the plant lectin GSA-II (Nakayama et al. 1999; André et al. 2016).

A large group of cytosolic and nuclear proteins, which carry multiple additions of a single $\beta$-O-GlcNAc unit linked to serine and threonine hydroxyl residues, has been reported. The same serine and threonine residues are also sites for phosphorylation, prompting consideration of a mutual relationship between these two modifications (Butkinaree et al. 2010; Ma and Hart 2014). The cycling of $\beta-O$ GlcNAc and phosphate has functional roles and is mediated by an $O$-GlcNAc transferase (Zimmerman et al. 2000) and an $N$-acetyl-D-glucosaminidase (Zhu-Mauldin et al. 2012). $O$-GlcNacylation is common throughout the metazoans.

Further $O$-glycan families have been identified. $O$-Mannose $\alpha$-linked to serine and threonine residues is commonly found in the metazoans, largely in skeletal muscle and 
Table 2 Mucin core structures

\begin{tabular}{|c|c|}
\hline Core type & Structure \\
\hline 1 & $\begin{array}{c}\mathrm{O}^{\beta 1-3} \square \\
\mathrm{Gal} \beta 1-3 \mathrm{GalNAc}\end{array}$ \\
\hline 2 & 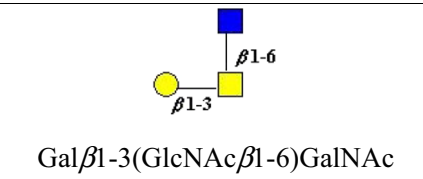 \\
\hline 3 & $\begin{array}{c}\square^{\beta 1-3} \square \\
\text { GlcNAc } \beta 1-3 \text { GalNAc }\end{array}$ \\
\hline 4 & GlcNAc $\beta 1-3(\operatorname{GlcNAc} \beta 1-6)$ GalNAc \\
\hline 5 & $\begin{array}{c}\square^{\alpha 1-3} \\
\text { GalNAc } \alpha 1-3 \text { GalNAc }\end{array}$ \\
\hline 6 & $\begin{array}{c}\square_{\beta 1-6} \\
\square \\
\text { GlcNAc } \beta 1 \text {-6GalNAc }\end{array}$ \\
\hline 7 & $\prod^{a 1-6}{ }_{\text {GlcNAc } \alpha 1-6 \text { GalNAc }}$ \\
\hline 8 & $\overbrace{}^{\alpha 1-3} \square$ \\
\hline
\end{tabular}

$O$-Glycan core structures found in eukaryotic mucins. Key: yellow circles, D-galactose; yellow squares, $N$-acetyl-D-galactosamine; blue squares, $N$-acetyl-D-glucosamine; all glycosidic linkages are shown as $\alpha$ or $\beta$; from Corfield (2015), with permission

the brain and nervous system (Lommel and Strahl 2009; Vester-Christensen et al. 2013; Panin and Wells 2014; Neubert and Strahl 2016). A tetrasaccharide, Neu5Ac $\alpha 2,3 \mathrm{Gal} \beta$ $1,4 \mathrm{GlcNAc} \beta 1,2 \mathrm{Man} \alpha \mathrm{Ser} / \mathrm{Thr}$ is found in the skeletal muscle protein $\alpha$-dystroglycan, and most $O$-mannose glycans are related to this structure despite additional modifications with fucose, glucuronic acid and sulphate (Panin and Wells 2014).

Proteins with epidermal growth factor domains carry glycans $O$-linked to peptide serine or threonine through $\alpha$-fucose and $\beta$-glucose. Urokinase, factor XII, cripto factor IX, thrombospondin type 1 repeats, Notch, Delta and Serrate have been identified. The epidermal growth factor (EGF) domains of these proteins carry the $O$-fucosylated glycans of the type Neu5Ac $\alpha 2,3 / 6 \mathrm{Gal} \beta 1,4 \mathrm{GlcNA}$ c $\beta 1,3 \mathrm{Fuc} \alpha \mathrm{Ser} / \mathrm{Thr}$, or smaller and a consensus sequence $\mathrm{Cys}^{2} \mathrm{X}_{4-5} \mathrm{Ser} / \mathrm{ThrCys}^{3}$ has been identified (Takeuchi and Haltiwanger 2014). The most common $O$-glucosyl structure is $(\mathrm{Xyl} \alpha 1,3 \mathrm{Xyl} \alpha 1,3 \mathrm{Glc} \beta-O-)$ and a peptide consensus domain $\mathrm{Cys}^{1} \mathrm{XSerXProCys}{ }^{2}$ reported (Gebauer et al. 2008; Takeuchi et al. 2012). The disaccharide, Glc $\alpha 1,2 \mathrm{Gal} \beta$-, found in collagen, is well known. The posttranslational modifications of the peptide to create the hydroxylysine and hydroxyproline generate the sites for $\beta$ - $O$-galactosylation to form Glc $\alpha 1,2 \mathrm{Gal} \beta-O$-Hyl/Hyp (Schegg et al. 2009).

A peculiar type of protein glycosylation, without a typical glycosidic bond, is formation of $\mathrm{C}-\mathrm{C}$ linkages between $\alpha$-mannose and the indole unit of tryptophan residues. The motif WXXW carries the glycans and is found in the Cys-D domains of several mucins, including the mucins MUC2, MUC5AC and MUC5B. The number of Cys domains varies between mucins, with 2 in MUC2, 7 in MUC5B and 9 in MUC5AC (Hofsteenge et al. 1994, 2001; Perez-Vilar et al. 2004; Ambort et al. 2011). Cys domains function in protein folding and mediate subcellular localization and trafficking in the endoplasmatic reticulum and Golgi membranes (Perez-Vilar et al. 2004; Ambort et al. 2011). C-Mannosylation in the mucin Cys domains governs the normal development and secretion of the mucins and when faulty induces ER stress, with mucins remaining in the ER (Desseyn 2009). Strengthening of the mucus layer in the gut lumen could be achieved by delivery of a tandem repeat molecule containing 12 repetitive Cys domains (Gouyer et al. 2015; Desseyn et al. 2016).

Many proteins possess a glycosylphosphatidylinositol (GPI) membrane anchor, attached to their carboxyl terminal. This ensures presentation of the protein on the external cellular surface where many important biological events occur (Ferguson et al. 2009; Shams-Eldin et al. 2009). As the anchor can be cleaved by phosphatidylinositol phospholipase $\mathrm{C}$, release of the protein can be mediated by the cell and correlated with function at the site of expression. The basic core structure of the GPI anchor is ethanolamine-phosphate-6Man $\alpha 1,2 \mathrm{Man} \alpha 1,6 \mathrm{Man} \alpha 1,4 \mathrm{GlcN} \alpha 1,6-$ myoinositol-1-phosphate-lipid. Proteins are attached to the amino group of the ethanolamine through their C-terminal carboxyl groups. A number of variations on this core are found, of particular interest is the addition of a palmityl group to the $\mathrm{C} 2$ group of myo-inositol as this blocks the action of phosphatidylinositol phospholipase $\mathrm{C}$ and regulates the biological half-life of the GPI protein in the membrane. GPI anchors are common across all Eukaryotes (Ferguson et al. 2009; Shams-Eldin et al. 2009). 
In order to generate the spectrum of glycan structures found on proteins, and indeed other glycan carriers such as lipids [for an introduction to glycolipids, please see Kopitz (2017) in this issue], individual cells must synthesize the glycans, with the required sequence. The metabolic pathways that are responsible for this process include the generation of a series of precursors from monosaccharides, the nucleotide sugars; sugar transporters that ensure that the necessary intermediates are available in the cell to generate the precursors; glycosyltransferases, which transfer the sugars to the acceptor protein to form the desired glycan structure, plus a number of other proteins which contribute to the formation of the final glycoprotein structure designed for specific biological function (Schachter and Brockhausen 1992; Liu et al. 2010; Corfield 2015); insights into details of branch-end elaborations, typically by sialylation, are presented by Bhide and Colley (2017, in this issue). These pathways are integrated to allow additional manipulation of the product glycoprotein. They also include catabolic manipulations, which may be linked to normal turnover and degradation, or specific modifications, which generate biologically active glycoforms and the salvage pathways feed back into the overall metabolism of glycoprotein metabolism. Further detailed information regarding glycobiology in this context can be found on the CAZy and Consortium for Functional Glycomics websites, see http:// cazy.org and http://functionalglycomics.org.

It is clear that this is a complex system, with many options necessary to form required glycoproteins at specific cell sites. Much of this specificity is achieved through the selective expression of glycosyltransferases, such that the combination allows only certain structures to be formed. The omission of glycosyltransferases will preclude the formation of certain glycans. As the glycan sequence is generated on a non-template basis, in contrast to nucleic acids and proteins, this is the remaining metabolic option to achieve any kind of sequence specificity and is clearly open to error through metabolic fluctuation (Brockhausen 2003; Breitling and Aebi 2013; Takeuchi and Haltiwanger 2014; Corfield 2015; Corfield and Berry 2015; Neubert and Strahl 2016).

\section{Glycosylation in organisms}

The global presence of protein glycosylation in the living world implies important biological function and development during evolution. It is to be expected that the structural features and physiological advantages will be carried forward, passed across species and provide biological markers in organisms. This section draws on examples of glycan occurrence and details the development relevant to the Eukaryotes. Several reviews contain a broad overview of these aspects with regard to the Eukaryotes and should be used as a supplement to this paper, e.g. Wilson (2002), Gerken et al. (2008), Dell et al. (2010), Lauc et al. (2014), Corfield and Berry (2015), Xu and Ng (2015). Much of the background to established glycosylation patterns in the Eukaryotes is in parallel with that reported for bacterial systems (Bäckhed et al. 2005; Moran et al. 2011; Tan et al. 2015) and it is certainly helpful to consider the bacterial systems, as they have a range of evolutionary aspects of interest.

The glycocalyx is a major characteristic of Eukaryote cells (see section "Glycosylation in cells"). It is this surface location where major interactions between cells takes place and enables communication and recognition processes to take place. Knowledge of the structural features is essential if the communication and functional elements of Eukaryote physiology are to be understood. They enable design of experimentation to reveal the precise nature of these interactions and provide a basis for the preparation of analogues and inhibitors to dissect the biological pathways involved.

As indicated in "Glycosylation of proteins" section, the chemical nature of glycans lends itself to the construction of structures with considerable variety and therefore excellent possibilities to adopt a system, which codes for functional roles in biology. It is significant that although a wide range of sugars are available in biological environments the glycan structures found in nature is limited, suggesting that a selection has occurred during evolution. Many glycan structures are shared across Eukaryotes. The core structures identified for the main groups of glycans listed in Table 1 are found in all groups of Eukaryotes. This is true for $\mathrm{N}$-glycans, $\mathrm{O}$-glycans, C-mannose and glycosaminoglycans, in addition to glycolipids (see Kopitz 2017, this issue). Further elaboration of the core elements is achieved through pathways that are also shared across the Eukaryotes, but have been adapted to yield strain and phylum-specific glycans and provide a unique glycosylation pattern. The pathways necessary to achieve both core and peripheral glycans are also shared across the Eukaryotes and further underline the utilization of selective processes acting in evolution (Bertozzi and Rabuka 2009; Springer and Gagneux 2016).

It is also evident that differences exist between the phylogenetic groups comprising the Eukaryotes. The fungi are unable to synthesize proteins containing sialic acids, complex $N$-glycans, $O$-glycans glycosaminoglycans or single $\beta$-linked GlcNAc. The green plants, Viridiplantae, do not synthesize sialic acids, phosphomannose units on high-mannose $N$-glycans, or $\beta 2$-linked GlcNAc on peripheral mannoses in $N$-glycans and generate plant-specific $N$-glycans with fucosyl and xylosyl units (Etzler and Mohnen 2009). O-Glycans are formed but show considerable differences to the Deuterostomes with no mucin-type 
proteins present and the main $O$-glycosylated products being hydroxyproline-rich glycoproteins (Wilson 2002). The nematodes also fail to synthesize sialic acids and do not form mucins. $\mathrm{N}$-glycans are processed to yield paucimannose forms, while $O$-glycans are based on the core 1 disaccharide, but contain $\beta$-glucose, $\beta$-glucuronic acid and fucosylation patterns not seen in vertebrate glycosylation (Corfield and Berry 2015, supplemental material). Finally, the arthropoda synthesizes chitin as the major polymer found in the cuticular exoskeleton. Sialylation has been detected in $\mathrm{N}$-glycans, but at low levels, in contrast to the vertebrates. $O$-glycans are also present, but appear to be limited to the core 1 disaccharide as no extended or branched glycans have been reported. In contrast, the Deuterostomes comprise the widest range of organisms sharing common glycan patterns (Corfield and Berry 2015, supplemental material).

\section{Glycosylation in cells}

"Introduction" and "Glycosylation of proteins" sections serve to demonstrate that there are many examples where cellular glycosylation is employed to generate species-specific glycoproteins across the Eukaryotes. The mammals are the main source of data and form the basis for examples here. Mucosal surfaces throughout the mammalian body are adapted to provide function and communication with their specific environment. There is clearly a range of mucosae that can be identified, but only some of these have been examined in any detail. The examples given here serve to illustrate the basic properties and provide a basis for the reader to compare with the following other Eukaryotes and individual tissues where less information is available, starting with the glycocalyx (Habermann and Sinowatz 2009; Habermann et al. 2011; for details on the zona pellucida as an example for a glycocalyx, please see Manning et al. 2017).

As emphasized above, it is clear that glycosylation is present in the form of glycoconjugates throughout the cell. The cell surface has attracted most attention, as this is the interface where many crucial biological interactions occur. Glycosylation of proteins is the mechanism used by prokaryotes and Eukaryotes to form a base for recognition and other essential processes within the cell. These allow biological programming of proteins for selective functions. Examples include basic protein properties such as stability within defined biological environments (Lee et al. 2006; Saludes et al. 2010; Tran and Ten Hagen 2013), protein folding (Helenius et al. 1997; Petrescu et al. 2000; Aryal et al. 2010; Xu et al. 2013), intercellular trafficking (Lowe 1997; Huet et al. 2003), co-translational quality control (Helenius 2001; Xu and Ng 2015; Roth and Zuber 2017), protein maturation and half-life, also tested with synthetic glycans as signal to infer structure-activity relationships (Morell et al. 1971; Ashwell and Morell 1974; Jee et al. 2007; André et al. 1997, 2007; Unverzagt et al. 2002; Chen et al. 2012; Mi et al. 2014), mediation of cell interactions in the extracellular matrix (Bassaganas et al. 2014), hostmicroorganism recognition (Alemka et al. 2012; Hajishengallis et al. 2012) and cell-cell binding processes such as sperm-egg adhesion (Mengerink and Vacquier 2001; Velásquez et al. 2007; Pang et al. 2011).

All cells have an apical glycocalyx, which provides a dynamic barrier to allow communication with the external environment of each epithelial cell. This is a common feature across the Eukaryotes. This is a structural feature of the surface membranes and consists of an arrangement of glycoproteins and glycolipids as an array (see, e.g., Kesimer et al. 2013; Tecle and Gagneux 2015; Woods et al. 2015; Huang and Godula 2016). The glycans serve as recognition components for proteins that bind them, mediating many biological events, e.g. fertilization (Mourao 2007; Tecle and Gagneux 2015), embryogenesis (Baskin et al. 2010), tissue development and conservation (Hart and Copeland 2010; Wells et al. 2013), and including immune interaction at both the innate and adaptive levels (Paulsen 2008; Johansson and Hansson 2016) and disease progression. Individual glycan binding potencies are known to be weak; however, multivalent presentation, as a glycoside cluster in the glycocalyx, greatly reinforces the overall binding affinity and enhances discrimination. In addition, the levels of glycans present in the glycocalyx elicit responses in signalling pathways. Thus, specific densities of glycans in the glycocalyx can trigger cellular action through different signalling pathways.

Established histochemical and electron microscopic methods used to visualize the glycocalyx cause destruction of the mucus layer and disrupt the organization of the glycocalyx (Stonebraker et al. 2004; Ebong et al. 2011; Kesimer et al. 2013). Several improved techniques have been utilized to visualize the true thickness of the mucus layer, including the glycocalyx, in several mucosal systems (Pullan et al. 1994; Atuma et al. 2001; Strugala et al. 2003), see Fig. 4, and more recently under conditions where the dynamics of glycocalyx synthesis, mucus secretion and modulation of mucus thickness can be studied (Gustafsson et al. 2012). The glycocalyx is characterized by an abundance of membrane-associated mucins (MUC), such as MUC1, MUC4, MUC12, MUC16 and MUC20. These are expressed on a tissue-specific basis, although MUC1 appears to be common to most mucosal surfaces (Argüeso et al. 2003; Hattrup and Gendler 2008; Linden et al. 2008; Govindarajan and Gipson 2010; McGuckin et al. 2011; Corfield 2015).

It is important to emphasize that the mucosal surface epithelium throughout the mammalian body is comprised 


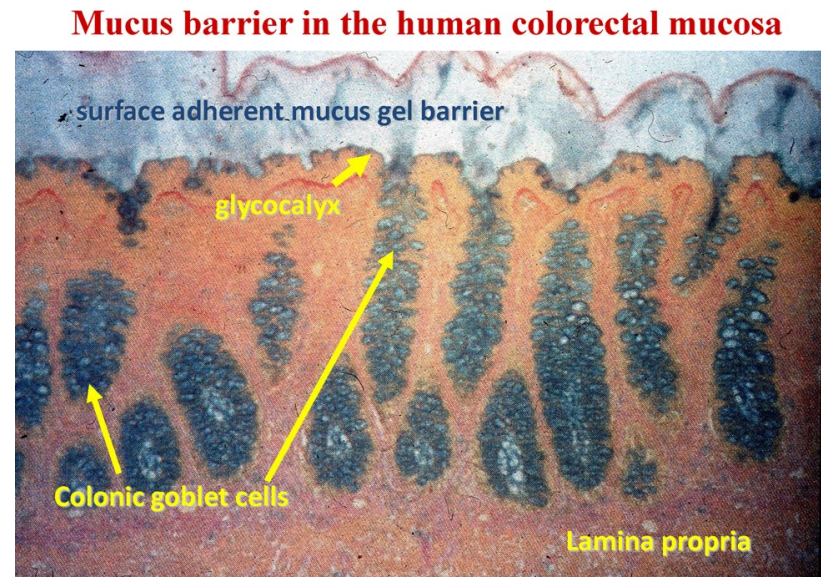

Fig. 4 Intestinal mucus barrier. Mucosal sample stained histochemically with Alcian Blue and Van Gieson counterstain after stabilizing the mucus gel layer by cryostat and molten agar. The image shows the secreted gel layer, glycocalyx, goblet cells and lamina propria from human colon; from Pullan et al. (1994), with permission

of a range of different cell types, each of which plays a role in general terms to provide a dynamic mucosal protective barrier (Gipson 2005, 2007; Johansson and Hansson 2013, 2016; Johansson et al. 2013; Birchenough et al. 2015). Mucus-producing cells have been identified in tissues where the secreted mucus layer is an essential feature of mucosal protection. The gastrointestinal epithelial cells that secrete mucus are the goblet cells, Tuft cells and Paneth cells. Other cells include the intestinal enterocytes and enteroendocrine cells, which are non-mucus-secreting cells. All of these cells are continuously renovated from stem cells located at the base of the crypt to maintain the proportions of these cells found under normal conditions. The intestinal enterocytes are the principal cells found in the intestinal mucosa and express many membrane-associated mucins on their glycocalyx. They are not concerned with significant secretion of mucus-type glycoproteins into the adherent mucus layer, but due to their abundance in the mucosal cell layer throughout the gastrointestinal tract their apical surface membrane domain makes a significant contribution to biological activity. Cell surface interactions are mediated through the glycan-rich zones of the mucins, which extend into the gastrointestinal lumen for a distance of up to $1 \mu \mathrm{m}$ (Johansson and Hansson 2016). The mucins found have a typical pattern of expression throughout the whole intestine and may relate to general and specific biological roles. The precise pattern of glycans presented by these mucins throughout the intestinal tract is not well understood, but clearly links with function and remains an ongoing target for future research (Pelaseyed et al. 2014; Reunanen et al. 2015).

In the gastrointestinal tract, the interactions of the host with the resident microflora are regulated through immune system by presenting a range of antigens to allow maturation of lymphoid tissues. Peyer's patches and the lamina propria are the sites where this occurs. Peyer's patches have a characteristic dome shape and the $\mathrm{M}$ cells located in these regions phagocytose antigens to enable this process (Kraehenbuhl and Neutra 2000; Ermund et al. 2013a, b). The mucus layer at the surface of the Peyer's patches is thought to be modulated, in order to allow easier sampling of bacteria. This may be due to the down-regulation of synthesis and secretion in those mucus-secreting cells bordering the Peyer's patches, absence of mucus-secreting cells directly over the Peyer's patches, or perhaps due to mucinolytic activities secreted by cells in the Peyer's patches. However, this remains a controversial issue as dynamic mucus spreading and continuity along the surface lumen of the gastrointestinal tract is believed to occur. In addition, further experimentation is necessary to define the role of glycosylation in the recognition process, which mediates transfer of luminal material during sampling events.

Tuft cells, also known as brush cells, present as a fraction of small intestinal and respiratory tract epithelial cells and are responsible for sensing the microflora (Bezencon et al. 2008; Howitt et al. 2016). The location of Tuft cells as intestinal epithelial and respiratory tract, tracheal cells means that they will have direct contact with the parasites and microflora in the lumen of the gut and in respired air and therefore may contribute to homeostasis (Parfrey et al. 2014). These cells mediate type 2 immunity and are thought to recognize parasites. Some aspects of the glycobiology of Tuft cells have been examined (Gebhard and Gebert 1999), but there are no recent studies using modern methods. Furthermore, examination across the different phylogenetic groups comprising the Eukaryotes is only partly complete. These remain important aims to improve our understanding of cellular biology at all mucosal surfaces.

The gastrointestinal mucosal cells responsible for the synthesis and secretion of the mucus barrier are the goblet and Paneth cells. These two cell types form part of the single layer of epithelial cells found at mucosal surfaces. The Paneth cells are largely found in the small intestine and are closely linked with the synthesis and secretion of a range of inhibitors of bacterial growth, including the defensins (Bevins and Salzman 2011; Ouellette 2011; Clevers and Bevins 2013; Salzman and Bevins 2013). Paneth cells have been reported to secrete MUC2 (Johansson and Hansson 2016); however, there are no glycobiological data and the contribution to the mucus layer on the mucosal surface has not been assessed.

The goblet cells, named because of their shape, are typically identified due to the copious granules containing mucins, present in their apical region are abundant throughout the body. These cells have been identified in the salivary 
glands (Nieuw Amerongen et al. 1995; Tabak 2006; Rousseau et al. 2008; Kozak et al. 2016); the ocular surface in the conjunctiva (Gipson and Inatomi 1998; Gipson 2007); the oesophagus (Flejou 2005); the stomach (Reis et al. 1999); the duodenum (Buisine et al. 2000); the small intestine (Ermund et al. 2013a, b); the colorectum (Agawa and Jass 1990); the upper and lower airways (Rose and Voynow 2006; Thornton et al. 2008; Davies et al. 2012; Kreda et al. 2012); the male (D'Cruz et al. 1996) and female (Gipson 2001) reproductive tracts; the pancreas (Buisine et al. 2000) and the hepatobiliary system (Buisine et al. 2000).

The secreted mucus barrier is necessary to withstand the mechanical and physiological forces encountered in the intestine during peristalsis, to provide lubrication. It also provides innate and adaptive immunological protection (Johansson and Hansson 2016) and, furthermore, is designed to filter luminal material and nutrients and to interact with the microflora, including pathogens and parasites present in the gastrointestinal lumen (Hasnain et al. 2013; Johansson and Hansson 2016).

The mucus layer secreted by the goblet cells has a characteristic thickness and structure depending on the location of the mucosal surface. For example, in the gastrointestinal tract the thickness is greatest in the stomach and large intestine, typically around $700 \mu \mathrm{m}$, while the small intestine ranges between 150 and $300 \mu \mathrm{m}$ (Atuma et al. 2001; McGuckin et al. 2011; Gustafsson et al. 2012). In the human colon a two-layer system is formed, the inner adherent layer composed of a network of MUC2 sheets, which is in contact with the mucosal cells and is resistant to penetration by the bacterial microflora (Johansson et al. 2008; Ambort et al. 2012). The outer layer is less organized and accommodates bacteria (Ambort et al. 2012).

Recent evidence has been presented that the goblet cells in the human colonic crypts are not equivalent (Birchenough et al. 2015, 2016). A sentinel goblet cell has been identified which is located at the entrance to the colonic crypt. The cell endocytoses TLR, which activates the Nlrp6 inflammasome, generates calcium-dependent MUC2 release from the sentinel cell itself and an intercellular gap junction signal. The signal leads to MUC2 secretion in neighbouring goblet cells in the upper crypt (Birchenough et al. 2015, 2016). This pattern of regulation ensures efficient protection against bacteria at the entrance to the crypt (Fig. 5).

Whether there are differences in the glycosylation of the MUC2 secreted at the surfaces of the crypts, from either the sentinel cell or those neighbouring goblet cells, has not yet been examined. The pattern of MUC2 glycosylation in goblet cells further down the crypt, which are not influenced by the sentinel cell, should also be considered. The picture that emerges is of a sophisticated defensive barrier system and not simply a MUC2 blanket.

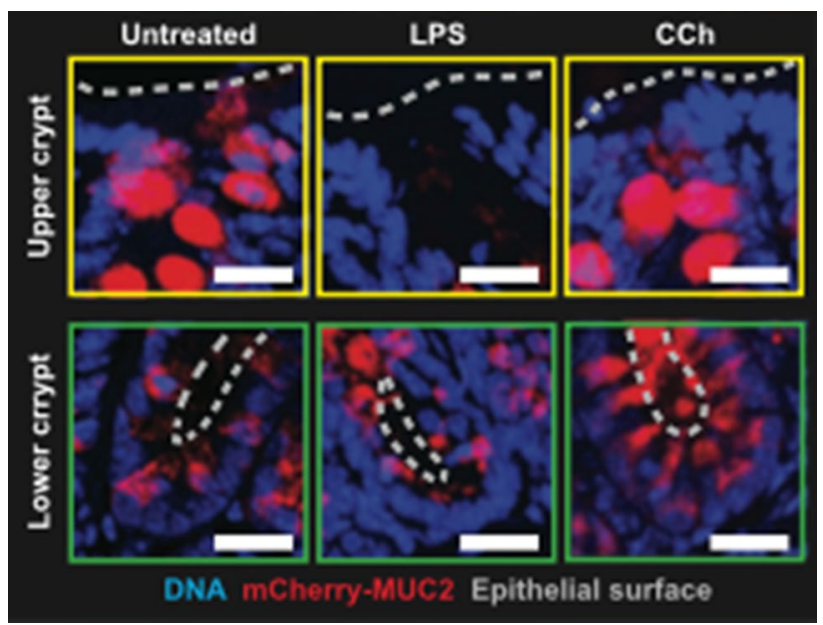

Fig. 5 Sentinel goblet cells in the human colon. Goblet cells responsive to Toll-like receptor ligands (TLR ligands) are located in the upper crypt. Cryosections in colonic explants treated with TLR ligands and visualized by confocal microscopy. Red MUC2; blue DNA. Upper crypt (yellow boxes) or lower crypt (green boxes). A dashed grey line shows the epithelial surface. Scale bars $20 \mathrm{~mm}$ From Birchenough et al. Science 352:1535-1542 (2016). Reprinted with permission from the American Association for the Advancement of Science (AAAS)

Goblet cells produce a number of factors, which play a significant role in the regulation of mucus metabolism and in mucosal protection. These factors are linked to the synthesis of glycoproteins and have a role in glycobiological management (Rodríguez-Piñeiro et al. 2013; Pelaseyed et al. 2014; Johansson and Hansson 2016). The maturation of goblet cells is mediated by the action of the transcription factor SAM pointed domain-containing Ets transcription factor. Two goblet cell-specific ER proteins, anterior gradient protein 2 homologue (AGR2) and ER-to-nucleus signalling (ERN2 or IRE1 $\beta$ ), are necessary for normal goblet cell MUC2 production (Johansson and Hansson 2016). The lectin-like protein ZG16 has been identified as an abundant goblet cell protein. It binds to the cell wall peptidoglycan of Gram-positive bacteria and leads to aggregation. These bacteria have reduced penetration of the mucus barrier at the colorectal surface, and ZG16 thus plays a role in keeping bacteria away from the mucosal surface (Bergström et al. 2016).

The trefoil factor family peptides are biosynthesized in the goblet cells and are closely linked to optimal organization of mucins and other glycoproteins in the secreted mucus barrier (Wright 2001; Hoffmann 2004; Albert et al. 2010). Resistin-like molecule is a cysteine-rich protein specifically produced by intestinal goblet cells and is thought to function in the mucosal barrier through regulation of inflammation (He et al. 2003; Artis et al. 2004; Wang et al. 2005). It has been shown to lead to colitis by depleting protective bacterial strains in the gut microflora (Morampudi et al. 2016). 


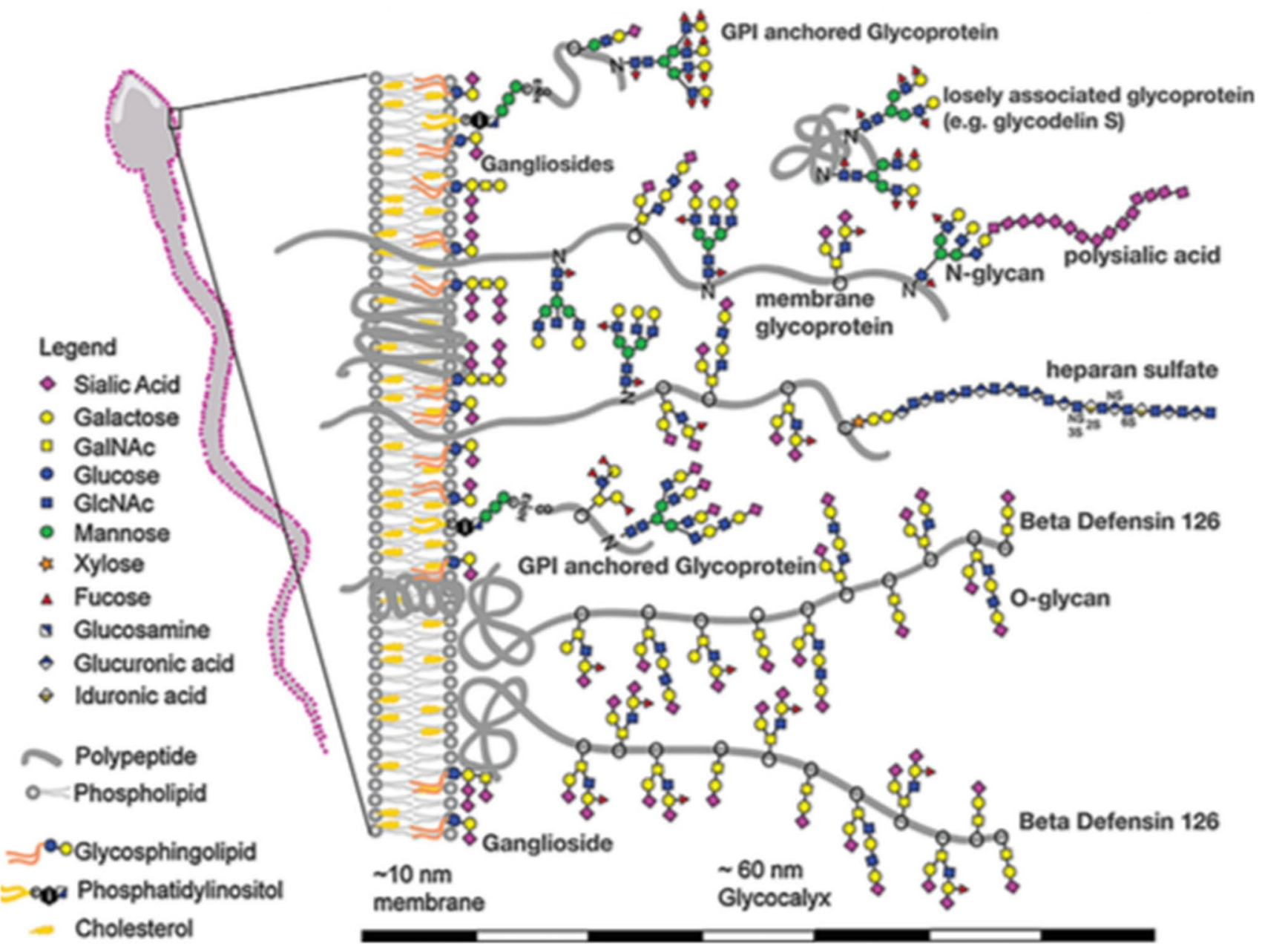

Fig. 6 Major glycan and glycoconjugate classes of human sperm glycocalyx. Monosaccharides are coded by coloured symbols shown in the figure. Proteins and lipids are grey, except cholesterol, and the lipids of glycosphingolipids. Mammals synthesize most glycans with

The oral cavity and salivary glands are the initial link with the oesophagus and gastrointestinal system. The salivary glands have been well studied, and information regarding the range of mucins and salivary proteins with their glycobiology is extensive (Veerman et al. 2003; Tabak 2006; Nieuw Amerongen et al. 2007; Tian and Hagen 2007; Rousseau et al. 2008; Kozak et al. 2016).

In the respiratory tract, the pseudostratified, ciliated and columnar tracheal and bronchiolar epithelial lining includes basal cells, secretory cells and ciliated cells. Ciliated cells are the most abundant, while goblet cells show a regional distribution being more numerous in the trachea than the bronchioles. The cells that secrete mucus are the goblet cells and mucus-small granule cells. In addition, the submucosal glands contribute a major part of secreted tracheobronchial mucus. They are abundant in the larger bronchi and have typical morphology with mucous and serous acini, a collecting duct and tubules and a ciliated duct. The a dozen different monosaccharide-building blocks; some of these monosaccharides can be further modified by sulphation and/or acetylation; from Tecle and Gagneux (2015), with permission

major glycoproteins synthesized in the respiratory tract are the mucins (Andrianifahanana et al. 2006). In man the main secreted mucins are MUC5AC, found exclusively in the epithelial goblet cells and MUC5B synthesized in the submucosal glands and associated ducts (Buisine et al. 1999; Kirkham et al. 2002; Sheehan et al. 2004; Voynow et al. 2006; Rousseau et al. 2007; Thornton et al. 2008). Low levels of MUC2 are produced in some goblet cells and the basal cells, while MUC7 is produced in the serous cells (Buisine et al. 1999; Copin et al. 2000; Vinall et al. 2000). The membrane-associated mucins MUC1 and MUC4 are detected in the tracheal epithelium (Hattrup and Gendler 2008), and expression of MUC3 (Apostolopoulos et al. 1995), MUC13 (Williams et al. 2001), MUC19 (Chen et al. 2004) and MUC20 (Higuchi et al. 2004) has been found. The molecular and physiological significance of this array of mucins remains to be clarified and the glycobiological data are limited, although characteristic glycosylation 
patterns for the respiratory tract are expected (Thornton et al. 1997, 1999, 2000; Holmén et al. 2004; Kesimer et al. 2013).

The human reproductive tract in both men and women has been a focus of attention, especially with regard to fertilization. However, it also provides a specific epithelial environment enabling the fertilization process and simultaneously supporting mucosal protection. As major glycoprotein components at animal mucosal surfaces, the mucins and sialoglycoproteins are prominent in male and female reproductive tracts (Audié et al. 1993; DeSouza et al. 1998; Lewis and Lewis 2012). There is ample evidence that the glycosylation of these molecules is an important factor for these molecules and plays a functional role in a number of different ways. This underlines, again, the flexibility of glycosylation as a dynamic and expansive mechanism adapted to specific physiological requirements. The physicochemical properties of the mucins are generated through the high proportion of glycans in these molecules (Lewis and Lewis 2012). A protective role for the mucins in the oviduct has been demonstrated with regard to both the migration of spermatozoa and the movement of fertilized ova to the uterus (Jansen 1995). Furthermore, manipulation of glycan chains through the action of mucinases and glycosidases such as sialidases plays both general and specific roles in man (Wiggins et al. 2001) and other Eukaryotes, including monotremes (Oftedal et al. 2014) and fish (Hunt et al. 2005)

The main partners in Eukaryote fertilization, the sperm and the egg have been studied extensively and functions for glycosylation clearly identified (Tecle and Gagneux 2015). Spermatozoa have been investigated across the spectrum of Eukaryotes and possess an abundance of glycoconjugates on their surface membranes, the glycocalyx, which extends for $60 \mathrm{~nm}$ from the membrane (Fig. 6). Among the glycoconjugates in the sperm glycocalyx are typical membrane glycoproteins with membrane anchor peptide domains together with glycoproteins anchored by a glycophosphatidylinositol unit (Franke et al. 2001; Mengerink and Vacquier 2001; Koistinen et al. 2003; Klisch et al. 2011; Tecle and Gagneux 2015). The glycobiology of these glycoconjugates has been defined (McCauley et al. 2002; Diekman 2003; Parry et al. 2007; Velásquez et al. 2007; Tecle and Gagneux 2015), and sialic acids play important roles (Yudin et al. 2008; Tollner et al. 2012; Silva et al. 2014). Important events in sperm-egg binding are mediated through the glycans on these molecules. Sialyl-Le ${ }^{\mathrm{x}}$ has been identified as a partner in sperm-egg binding (Pang et al. 2011).

Maturation of the sperm glycocalyx is necessary for penetration of the mucus barrier in the cervix and also provides protection against uterine immune defences. Both sialylation (Mengerink and Vacquier 2001; Miyata et al. 2004,
2006; Velásquez et al. 2007; Ma et al. 2012; Simon et al. 2013; Hänsch et al. 2014) and fucosylation (Mengerink and Vacquier 2001; Pang et al. 2007; Tecle and Gagneux 2015) play roles in the development, maturation and functional aspects of spermatozoa. The range of sialic acids has been shown to act as self-associated molecular patterns and are binding partners for proteins synchronizing the immune response such as the siglecs (Gabius 1997; Crocker 2005; Varki 2011). The migration of spermatozoa to the oviduct involves glycocalyx interactions with the follicular fluid and epithelial barrier of the uterus, leading to the formation of the oviductal sperm reservoir (Tecle and Gagneux 2015) and ultimately binding to the zona pellucida of the oocyte. Sperm capacitation occurs before fertilization and is necessary to allow the normal fertilization process to occur. This entails a substantial reorganization of the glycocalyx. Membrane-anchored glycoproteins are discarded, and specific desialylation occurs (Ma et al. 2012; Tollner et al. 2012; Tecle and Gagneux 2015).

The female reproductive tract mucosal cells have a typical glycocalyx and secrete a variety of glycoproteins in a hormonally mediated fashion. This leads to variation in thickness and porosity of the surface mucus gel, which correlate with sperm penetration and fertilization of the ova. Mucins and glycodelins are important and have glycoforms that vary throughout the menstrual cycle and accommodate the processes occurring during fertilization. Mucins identified include the secreted forms MUC5AC, MUC5B and MUC6, together with membrane-associated MUC1 and MUC16 (Gipson et al. 2001; Argüeso et al. 2002; Andrianifahanana et al. 2006; Andersch-Bjorkman et al. 2007; Gipson et al. 2008; Pluta et al. 2012; Corfield 2015). Over $50 \mathrm{O}$-glycans were detected including neural and acidic with both sialylated and sulphated forms. Ovulation was characterized by decreased sialylation and an increase in core 2 structures, while Neu5Ac $\alpha 2,6 \mathrm{GalNAc}$ - and Neu5Ac $\alpha 2,3 \mathrm{Gal}$-glycans were common in the non-ovulatory phases (Yurewicz et al. 1987; Andersch-Bjorkman et al. 2007).

A report on the action of hormones and bacterial flora on the female genital tract glycome during the menstrual cycle has recently appeared (Moncla et al. 2016) and identified MUC1, MUC4, MUC5AC and MUC7 with distinct glycosylation patterns identified using lectins (Moncla et al. 2016). This study demonstrates organized expression of both mucins and glycosylation during the menstrual cycle. The glycodelins are glycoproteins also found in the female reproductive tract. They are small, $28-$ to $30-\mathrm{kDa}$ glycoproteins of the lipocalin family and occur as three isoforms, each with two $N$-glycan chains (Seppala et al. 2002; Jayachandran et al. 2006; Yeung et al. 2006). Complex-type glycans were detected: Gal $\beta 1,4 \mathrm{Glc} N A \mathrm{c}, \mathrm{Gal} N A c \beta 1$, $4 \mathrm{GlcNAc}$, NeuAc $\alpha 2,6 \mathrm{Gal} \beta 1,4 \mathrm{Glc} N A \mathrm{c}, \mathrm{NeuAc} \alpha 2,6 \mathrm{Gal} \beta 1$, 
4GlcNAc, Gal $\beta 1,4$ (Fuc $\alpha 1,3)$ GlcNAc and GalNAc $\beta 1,4$ (Fuc $\alpha 1,3)$ GlcNAc (Dell et al. 1995). There is evidence that glycans with sialyl-LacNAc or LacdiNAc antennae play a role in immunosuppression, through CD22 and selectins (Dell et al. 1995). Sperm-zona pellucida binding is blocked by glycodelin and further emphasizes the importance of glycobiology in immune and gamete recognition processes (Dell et al. 1995).

In addition to the secretions associated with the mucosal surface, the cervical canal contains a mucus plug during pregnancy. Although this is a well-known mucus feature, it has received little interest compared to the other mucosal surfaces in the body (Becher et al. 2009). Most interest has focused on the rheological (Becher et al. 2009; Bastholm et al. 2016), microbial (Hansen et al. 2014), immunological (Hein et al. 2005; Lee et al. 2011) and protein degradative (Becher et al. 2010) properties. Protein profiling studies showed MUC1, MUC2, MUC5AC and MUC5B (Habte et al. 2008), but did not identify glycodelins (Habte et al. 2008; Lee et al. 2011). No glycan analysis of the mucus plug glycoproteins has been reported.

The jelly coat or extracellular matrix surrounding Deuterosome eggs is species-specific and linked to the process of sperm-egg fusion to achieve fertilization. While the echinoderms have a jelly layer and vitelline coat, mammals have a more complex arrangement with an external cumulus matrix overlying a zona pellucida (Mengerink and Vacquier 2001; Habermann and Sinowatz 2009; Habermann et al. 2011).

The ocular surface and tear film is a specially adapted mucosal surface which has properties and structures not seen at other mucosal locations. The conjunctiva is the mucosal surface where products composing the tear film are synthesized and secreted and together with the underlying stroma provides ocular defence and protection (Fig. 7). The conjunctival epithelium is composed of squamous and goblet cells which both secrete electrolytes. The mucins constitute the major molecules contributing to the structure and properties of the tear film (Berry et al. 1996; Pflugfelder et al. 2000; Gipson 2004, 2007; Paulsen 2008; Argüeso and Gipson 2012; Hodges and Dartt 2013). They address several biological requirements of the ocular surface. Physicochemical properties enable lubrication during blinking and spreading across the corneal and conjunctival surfaces, allow removal of debris accumulated on the eye surface and retain hydration to avoid dessication. These physicochemical properties are also designed to allow light through the barrier to give optimal vision. Mucins generate a stable gel layer where anti-microbial molecules, including lysozyme, transferrin, secretory IgA and other immunoglobulins, defensins and trefoil factor family peptides, can be maintained to achieve protection against infection

\section{CORNEAL EPITHELIUM}

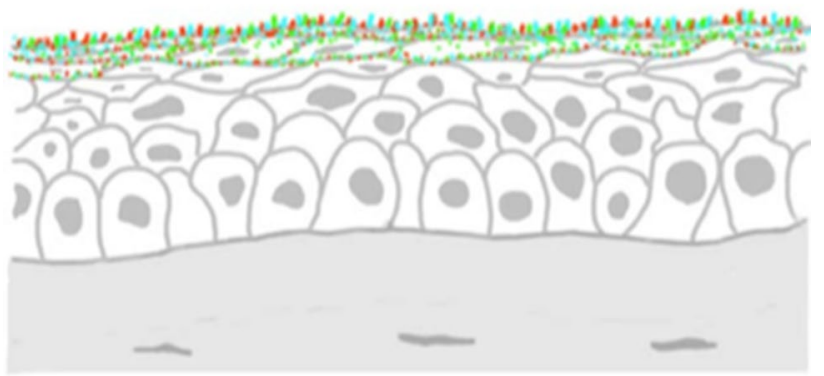

CONJUNCTIVAL EPITHELIUM

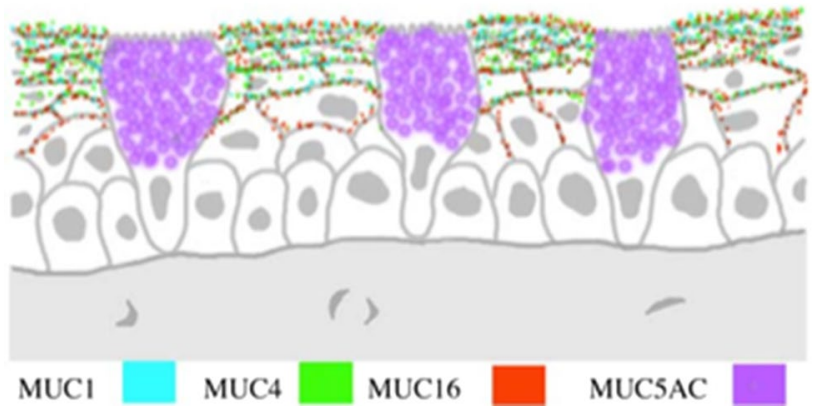

Fig. 7 Mucin expression in the human cornea and conjunctiva. Schematic of the location of mucins in the corneal and conjunctival epithelium. The membrane-associated mucins MUC1, MUC4 and MUC16 at the apical cell membrane glycocalyx, and the secreted mucin MUC5AC in goblet cell vesicles; from Gipson (2004), with permission

(Gipson and Argüeso 2003; Argüeso et al. 2009; Govindarajan and Gipson 2010).

The tear film is composed of three layers, an apical surface lipid layer, secreted by the Meibomian glands, an aqueous layer lying above the mucus layer, which has direct contact with the glycocalyx at the apical surface of cornea. The tear film is a dynamic entity, and each layer is constantly renewed.

The ocular mucins show a selective expression pattern, again emphasizing the adaptation of mucosal surfaces to environmental needs (Young and Clement 2000). MUC5AC is the major secreted mucin present, while MUC2, MUC5B, MUC7 and MUC19 have been detected at lower levels (Berry et al. 1996; Gipson 2004; Mantelli and Argüeso 2008). The glycocalyx of the stratified epithelium is rich in membrane-associated mucins, MUC1, MUC4 and MUC16 are most abundant (Argüeso et al. 2003; Paulsen and Berry 2006; Govindarajan and Gipson 2010; Hodges and Dartt 2013), and MUC15 and MUC20 have also been detected (Mantelli and Argüeso 2008). The lacrimal glands also contribute to the composition of tear film and MUC1, MUC2, MUC4, MUC5AC, MUC5B, MUC6 and MUC7 have been detected in the glands and the 
secreted mucins MUC5AC, MUC5B, MUC6 and MUC7 probably reach the tear film through the tear duct passage (Paulsen and Berry 2006).

The glycobiology of the ocular surface and tear film has been probed in several studies, where the significance of sialic acids is a common characteristic (Pflugfelder et al. 2000; Corfield et al. 2005; Argüeso and Sumiyoshi 2006; Argüeso 2008; Royle et al. 2008; Argüeso et al. 2009; Baos et al. 2012). Examination of the $O$-linked glycans released from the mucins in human, rabbit and canine ocular surface secretions revealed 12 different glycans, 6 of which were sialylated (Royle et al. 2008). Further chemical, lectin and antibody studies demonstrated that the $9-\mathrm{O}$-acetylated form of sialic acid was a characteristic feature of the ocular system (Corfield et al. 2005; Argüeso and Sumiyoshi 2006). Thus, a tissue-specific glycosylation programme operates at the ocular surface and emphasizes the versatility of the sugar code as a means to achieve biological specificity. Imaging of ocular mucins using atomic force microscopy has enabled mapping of the height of glycans on MUC5AC through binding of an anti-glycan antibody (Round et al. 2007). These data support proposals regarding the arrangement of mucin molecules in aqueous solution under physiological conditions.

The urinary tract is another example of a tissue where the mucosal surfaces have been adapted to allow specific function. Filtration of urine requires barrier properties not found at other mucosal sites. The renal mucins and kidneyspecific glycoproteins are well known (Serafini-Cessi et al. 2005; Aubert et al. 2009; Tringali et al. 2012; Weinhold et al. 2012). Especially with respect to sialic acid metabolism in glomerulus podocytes (Wagner and Roth 1985; Charest and Roth 1988).

The nervous system has attracted considerable attention and exhibits a characteristic pattern of molecular morphology having an array of tissue-specific molecules with characteristic glycosylation, as further described by Ledeen and Wu (2009) and by Higuero et al. (2017, this issue). A short overview is given here. Neural cell adhesion molecule (Zhou and Zhou 1996) is a member of the immunoglobulin superfamily of adhesion molecules and carries polysialic acid chains of varying size. These polysialic acid chains are $\alpha 2-8$ linked and have biological role in nervous tissue and especially the brain (Hildebrandt et al. 2007; Rutishauser 2008; Bonfanti and Theodosis 2009; Mühlenhoff et al. 2009; Zuber and Roth 2009; Schnaar et al. 2014). Neural stem cells express CD15 (Yu and Yanagisawa) coding Gal $\beta 1,4$ (Fuc $\alpha 1,3)$ GlcNAc $\beta 1$ - (Yu and Yanagisawa 2006), while $O$-mannosylation is also a significant feature of $\alpha$-dystroglycan in the nervous system, where it mediates cell-extracellular matrix contact (Hennet 2009; Panin and Wells 2014; Praissman and Wells 2014; Yaji et al. 2015).
The innate and adaptive immune systems have been extensively scrutinized regarding their glycobiology (Bäckhed et al. 2001; Royle et al. 2003; Bevins 2004; Rudd et al. 2004; Brockhausen 2006; Crocker et al. 2007; Marth and Grewal 2008; Hooper et al. 2012; Kolarich et al. 2012; Rabinovich et al. 2012; Bull et al. 2014; Gerbe and Jay 2016; Johansson and Hansson 2016).

\section{Glycosylation and disease}

There are many examples of aberrant glycosylation playing a role in disease processes. This part uses a few examples to highlight the relationship between incorrect glycosylation, biological recognition and the resulting changes that lead to abnormal function and pathology. The techniques employed to detect changes in protein glycosylation are those outlined in "Glycosylation of proteins" section.

The development of cancer in the human gastrointestinal tract has been closely studied as it falls into the category of a Western disease, linked with lifestyle and diet. Much work has focused on the mucosal changes associated with the development of the tumours, and inflammatory bowel disease (IBD) has proved to be instructive due to the number of patients who go on to develop cancer. From early days there have been indications that the changes in glycobiology are related to the process of malignant transformation. The routine histological screening of the gastrointestinal tract for early changes in disease remains an essential part of clinical assessment. Early detection is associated with positive prognosis, and regular screening during disease provides assessment of disease progression and gives indications for therapy including surgical intervention. The focus of this section is the lower bowel, the colorectum and the patterns associated with progression to cancer. Important chemical and biochemical information has been gathered regarding the pattern of glycosylation in mucins at different regions of the human colorectum (Robbe et al. 2003, 2004, 2005; Larsson et al. 2009; Holmén Larsson et al. 2013) and similarities that exist compared to the foetal mucins (RobbeMasselot et al. 2009). However, differences between MUC2 from human and murine colorectum have been shown and underline the need to take account of species-specific glycosylation when studying disease mechanisms (Thomsson et al. 2012). These data are important as it provides a chemical basis to consider the lectins and antibodies, which are valuable in screening tissue sections from patients.

The inflammatory bowel diseases, ulcerative colitis (UC) and Crohn's disease (CD), show characteristic morphological changes at the sites of disease, and colorectal tumours are also found at these sites. Endoscopic screening is used to locate regional mucosal disease along the colorectum, and both $\mathrm{UC}$ and $\mathrm{CD}$ have characteristic patterns of disease 
mucosa flanked by normal mucosa. Colonic biopsies taken at sites of disease together with resected tumours and polyps have been used for histological assessment.

Because the mucins expressed throughout the colorectum present the main glycan repertoire, tissue samples have been examined for both MUC gene expression and glycosylation patterns (Bartman et al. 1999; Kyo et al. 2001; Sylvester et al. 2001; Shaoul et al. 2004; Longman et al. 2006; Png et al. 2010; Corfield et al. 2011; Croix et al. 2011; Larsson et al. 2011; Sheng et al. 2012; Leone et al. 2013; Theodoratou et al. 2014).

The screening of mucins in the colorectum has identified MUC2 as the major product (Tytgat et al. 1994; van Klinken et al. 1997). Confirmation of the relevance of this gene to colorectal disease has come from $\mathrm{Muc}^{-/-}$ mice where the gene is deleted and increased susceptibility to spontaneous tumour formation occurs (Velcich et al. 2002). Other mucin changes in colorectal cancer have been reported for de novo expression of MUC5AC (Buisine et al. 1996, 2001; Myerscough et al. 2001; Kocer et al. 2002; Warson et al. 2002) and MUC 20 overexpression (Xiao et al. 2013). A number of studies have addressed the glycosylation of mucins in both IBD and colorectal cancer and the progression through different stages from adenoma to carcinoma (Fig. 8). The importance of the attachment of the $O$-glycans to mucin proteins was demonstrated with studies on the core 1 disaccharide Gal $\beta 1,3 \mathrm{GalNAc-}$, also called TF antigen (Campbell et al. 2001; Bergström et al. 2016), and the core 3 GlcNAc $\beta 1,3 \mathrm{Gal} N A c$ structures (Iwai et al. 2005). Loss of genes coding for the formation of these cores led to development of colitis and cancer. Malignant change leads to a reduction in the size of the glycans on mucins and an enrichment of the truncated glycans, Tn (GalNAc- $\alpha$-Ser/Thr), sialyl-Tn (Neu5Ac $\alpha 2,6 \mathrm{Gal} N A c-\alpha-$ Ser/Thr) (Itzkowitz et al. 1990; King et al. 1994; Jass et al. 1995; Brockhausen et al. 1998; Marcos et al. 2011) and the TF antigen Gal $\beta 1,3 \mathrm{Gal} N A \mathrm{c}-\alpha \mathrm{Ser} / \mathrm{Thr}$ (Baldus et al. 2000; Campbell et al. 2001). Interestingly, these epitopes are targets of diverse tissue lectins such as C-type lectins as the macrophage receptor, with different impact on the fate of the tumour cells ranging from defence to growth stimulation (Marcelo et al. 2014; Rodriguez et al. 2015; Beatson et al. 2016). Changes in mucin sialylation are also evident with an increase of sialyl-Le ${ }^{\mathrm{x}}$ (Hanski et al. 1995; Grabowski et al. 2000; Robbe-Masselot et al. 2009) and the loss of the $\mathrm{Sd}^{\mathrm{a}}$ antigen, GalNAc $\beta 1,4(\mathrm{Neu} 5 \mathrm{Ac} \alpha 2,3)$ Gal $\beta 1,3 / 4 \mathrm{GlcNAc} \beta 1,3 \mathrm{GalNAc-}$ (Malagolini et al. 2007). Variation of sialytransferases in colorectal cancer accounts for these alterations (Dall'Olio et al. 1989, 2014). High levels of $O$-acetylated sialic acids are normally present in colonic mucins and are depleted in IBD and colorectal cancer (Corfield et al. 1992a, 1999; Mann et al. 1997; Shen et al. 2004). Changes in the $O$-glycan pattern for MUC2 have been reported in UC (Larsson et al. 2011).

Glycosulphation is a major feature of colonic mucins and is reduced in IBD and cancer. This has been shown using histochemical staining by the high iron diamine method and metabolic labelling with ${ }^{35} \mathrm{~S}$-sulphate (Corfield et al. 1992b, 1996; Campbell et al. 2001). Immunohistochemistry showed a reduction in sulpho- $\mathrm{Le}^{\mathrm{a}}, \mathrm{SO}_{4^{-}}$ $3 \mathrm{Gal} \beta 1,3$ (Fuc $\alpha 1,4) \mathrm{Glc} N A c \beta 1,3 \mathrm{Gal}$-staining (Longman et al. 2006).

Strong evidence supports a role for the microflora in the pathology of IBD and colorectal cancer (Knight et al. 2008; Png et al. 2010; Arthur and Jobin 2011; Candela et al. 2011; Fava and Danese 2011; Gentschew and Ferguson 2012; Natividad et al. 2012; Dalal and Chang 2014; Probert et al. 2014), and therapeutic faecal transplant is currently being used (Shanahan and Collins 2010; Damman et al. 2012). These aspects also link with the influence of the diet on disease (Albenberg et al. 2012; Neuman and Nanau 2012). Thus, interactions of the microflora in the gut with the host mucosa impact on the metabolic pathways regulating mucins and their glycosylation. Ethnicity has been found to be a factor in the nature of IBD and colorectal cancer. The lower rate of IBD in Indian populations compared with Caucasians could be confirmed using histological and metabolic labelling methods (Probert et al. 1993, 1995). This remains an underdeveloped aspect of gastrointestinal disease worldwide.

Necrotizing enterocolitis is the most common gastrointestinal condition known for premature, low-birth-weight neonates. It has a multifactorial aetiology, and its pathogenesis remains poorly understood. A combination of risk factors results in the attachment of bacteria to the immature and damaged mucosal barrier mucus. Maintenance of the cellular integrity of the mucosal barrier is crucial and correlates with a number of factors, including the trefoil factor family peptides, found in the goblet cells and which are responsible for regulating epithelial homeostasis through restitution and regeneration. Together with the mucins they provide effective mucosal barrier protection at this early stage of life. The glycobiology of this condition has not been examined, but demonstration that depletion of goblet cell TFFs occurs (Vieten et al. 2005), in this condition implies a role for in this condition (Fig. 9). In view of the better understanding of goblet cells and the existence of different types with specific roles, noted above under "goblet and Paneth cells and the secreted mucus layer", a closer examination of this phenomenon in NEC may lead to improved understanding of pathogenesis and protective measures.

Bacterial vaginosis is a common polymicrobial condition found in women. In women of childbearing age the 
Fig. 8 Loss of MUC2 and sulpho-Lewis ${ }^{\mathrm{a}}$ in ulcerative colitis. Detection of MUC2 glycoprotein by immunostaining with the Lum2-3 antibody for normal (a) and clinically severe UC (c). The same specimens were also tested for MUC2 mRNA for normal (b) and UC (d). Immunostaining for MUC2 in mucosa adjacent to an ulcer (e) showed reduced staining compared with normal intact mucosa (f). Detection of sulpho-Le ${ }^{\mathrm{a}}$ with the F2 antibody showed localization throughout the mucosa, including the mucus gel layer (g). Sulpho-Le ${ }^{\mathrm{a}}$ colitis (i), but was depleted at the luminal surface and upper crypts in severe colitis (h). In situ hybridization samples were counterstained with toluidine blue and immunohistological sections with haematoxylin; from Longman et al. (2006), with permission staining was preserved in mild
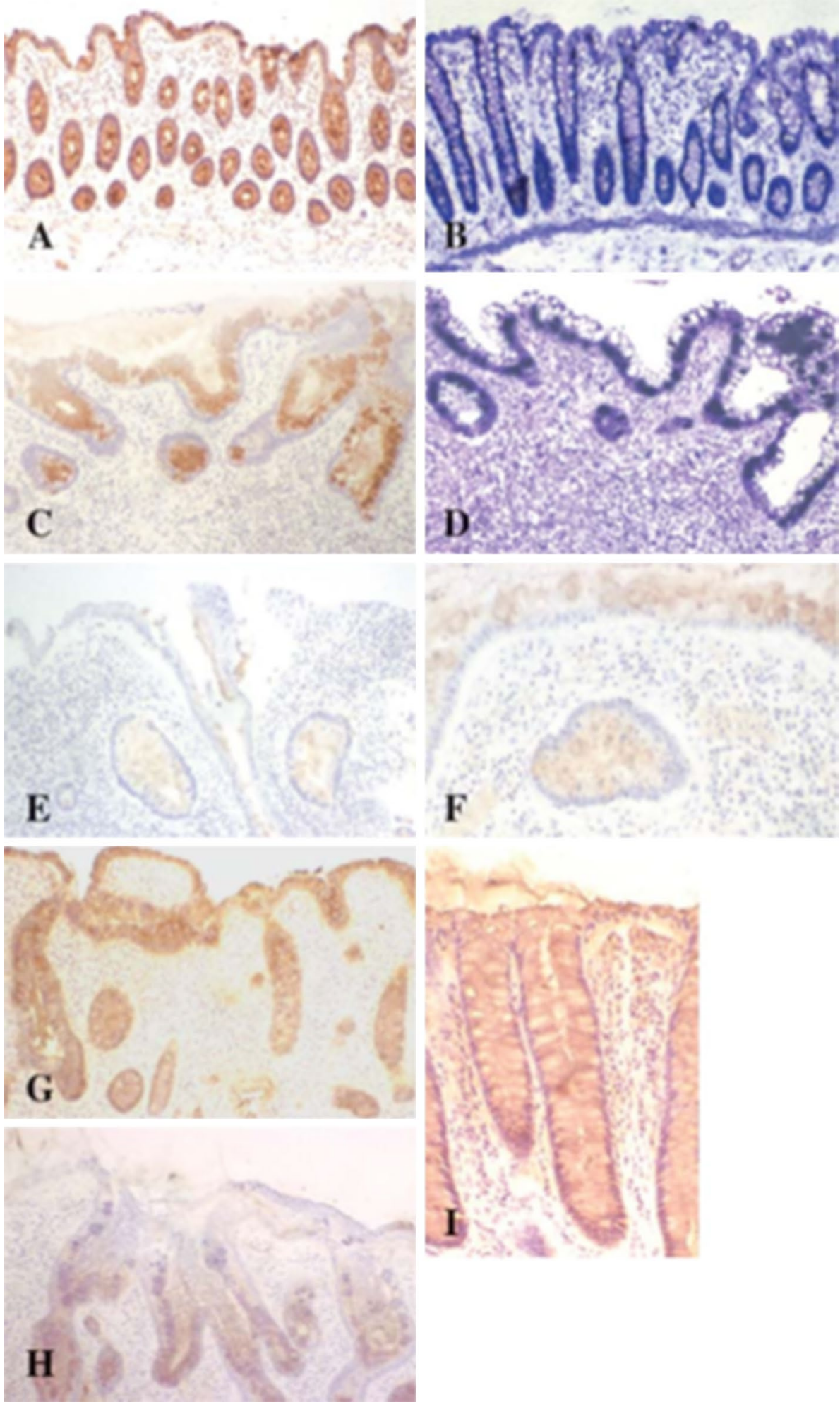

vagina is host to an abundance of bacterial strains dominated by Lactobacillus species (Onderdonk et al. 2016). The degradation carbohydrate by these bacteria produces lactic acid, which maintains a vaginal surface $\mathrm{pH}$ of around 4.5 , which is optimal for their growth. In BV an increase in mucosal $\mathrm{pH}$ to $6.0-7.0$ lead to a change in the microflora with a loss of Lactobacillus spp. and the appearance of other facultative and anaerobic strains including anaerobic cocci, Gardnerella vaginalis, Mobiluncus spp., Bacteroides spp., Prevotella spp., Peptostreptococcus spp. 
Fig. 9 Depletion of goblet cells in necrotizing enterocolitis. The trefoil factor family peptide TFF3 is shown with immunostaining (a) in normal neonatal colon $(x 10$ magnification), with staining of all goblet cells and the lumen (arrow).

Normal neonatal colon at $\times 40$ magnification shows a granular pattern of TFF3 in goblet cells (b). Reduction of goblet cells in a patient with NEC is shown at $\times 10(\mathbf{c})$ and $\times 40(\mathbf{d})$ magnification and reveals empty goblet cells (arrows in d), in particular at the surface epithelium; from Vieten et al. (2005), with permission

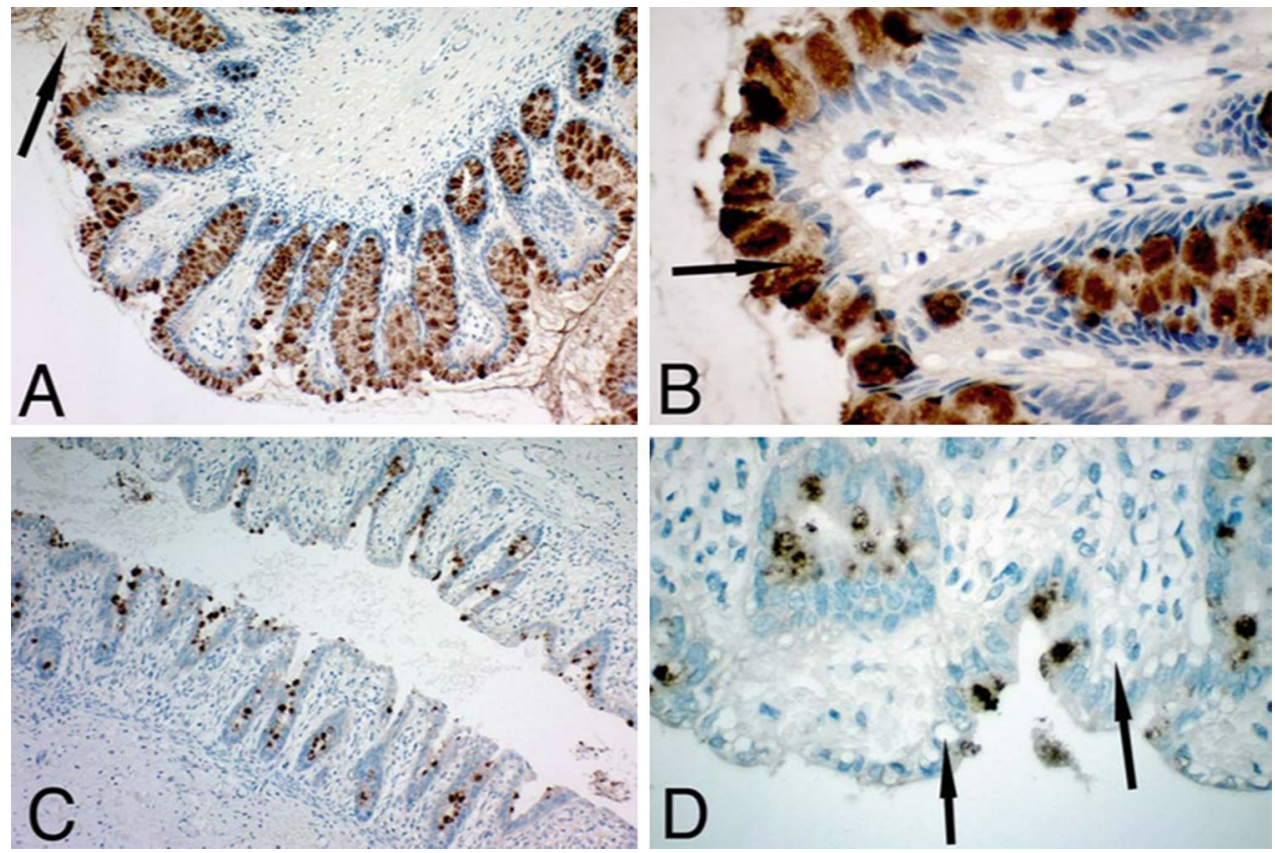

and Mycoplasma hominis. Clinically, this change leads to poor health outcomes including pelvic inflammatory disease, late miscarriage, spontaneous preterm birth and chorioamnionitis. Probiotic therapy has been used in disease management (Falagas et al. 2007). The cervicovaginal fluid (Wang et al. 2015) is part of the mucosal lining of the vagina and is analogous to the mucus barrier in other mucosae (Moncla et al. 2016). Cervical mucins and a range of other defensive proteins are present in the secretion and donate the major glycan composition present in this environment (Gipson 2001; Pluta et al. 2012). The secretory mucin genes MUC2, MUC5AC, MUC5B, MUC6 are found with major expression of MUC5AC and MUC5B (Gipson et al. 1999, 2001), while the membrane-associated mucins, MUC1, MUC4 and MUC16 are found at high levels (Gipson et al. 1999, 2001). Glycobiology plays a significant role in the pathology of BV. The action of mucinases and glycosidases, especially sialidases (Wiggins et al. 2000), has been demonstrated to be associated with the development of an abnormal mucosal barrier in the vagina (Wiggins et al. 2001; Moncla et al. 2015). In addition, the association of glycosulphatases in BV microflora has been found and implicates mucin sulphation as a feature of the normal and pathological state (Roberton et al. 2005). Review of the female genital tract glycome has confirmed this relationship and yielded a focus for future development and therapeutic intervention (Moncla et al. 2016).

The ocular surface and the tear film have been widely examined in mammals as detailed above under "The Ocular Surface". Among pathological conditions that affect the normal function is dry eye disease or keratoconjunctivitis sicca. In this disease, a number of morphological abnormalities of the lacrimal apparatus arise which cause instability and dessication of the preocular tear film and changes in the ocular surface mucus. A reduced number of conjunctival goblet cells are detected histologically (Vieten et al. 2005), and the mucus becomes more viscous and less easy to spread evenly over the corneal surface (Corfield et al. 2005).

Studies show that glycobiology plays a significant role in this disease (Argüeso 2008). Sialylated $O$-glycans were detected in human and canine mucus (Royle et al. 2008; Guzman-Aranguez et al. 2009) and a reduction in the expression of sialyl-Le ${ }^{\mathrm{a}}$ reported in dry eye tears (Garcher et al. 1998). Although increased sialylation was found in canine KCS (Carrington et al. 1998), the fraction of these sialic acids present as 9-O-acetylated sialic acid, largely in MUC 5AC mucins, was reduced or eliminated in KCS (Gipson et al. 2004; Corfield et al. 2005; Argüieso and Sumiyoshi 2006) (Fig. 10). These data emphasize the importance of glycobiology in understanding biological function.

The presence of amyloid deposits in the brain is a hallmark of Alzheimer's disease (AD) (Shoemark and Allen 2015) and increases with age in humans and is associated with progressive decline of cognitive function and dementia. The pathogenesis of AD is still poorly understood, but the identification of the accumulation of protein aggregates derived from amyloid precursor protein has been identified. The normal proteolytic processing of APP is implicated in $\mathrm{AD}$, and the resulting aggregates form a focus for the deposition of amyloid to generate senile plaques in the brain. Correlations of $\mathrm{AD}$ with the patterns of microbial colonization in the body and changes associated with increased age have been presented (Shoemark and Allen 2015), and 
Fig. 10 Histology of normal and KCS canine conjunctival tissues. Tissue sections from normal canine conjunctiva were stained with the antiMUC5AC antibody 21M1 (a); Alcian Blue/PAS (b); mild-PAS (c); SNA for $\alpha(2-6)$-linked sialic acids (d); WGA (e) and antibody TKH2 against sialylTn (sialyl- $\alpha$ (2-6)GalNAc) (f). Magnification is $\times 40$ in all cases. Histology of KCS canine conjunctival tissues. Tissue sections from animals with KCS stained with periodic acidSchiff/Alcian Blue (g) and high iron diamine/Alcian Blue (h). Magnification is $\times 40$ in both cases. Taken from Corfield et al. (2005) with permission
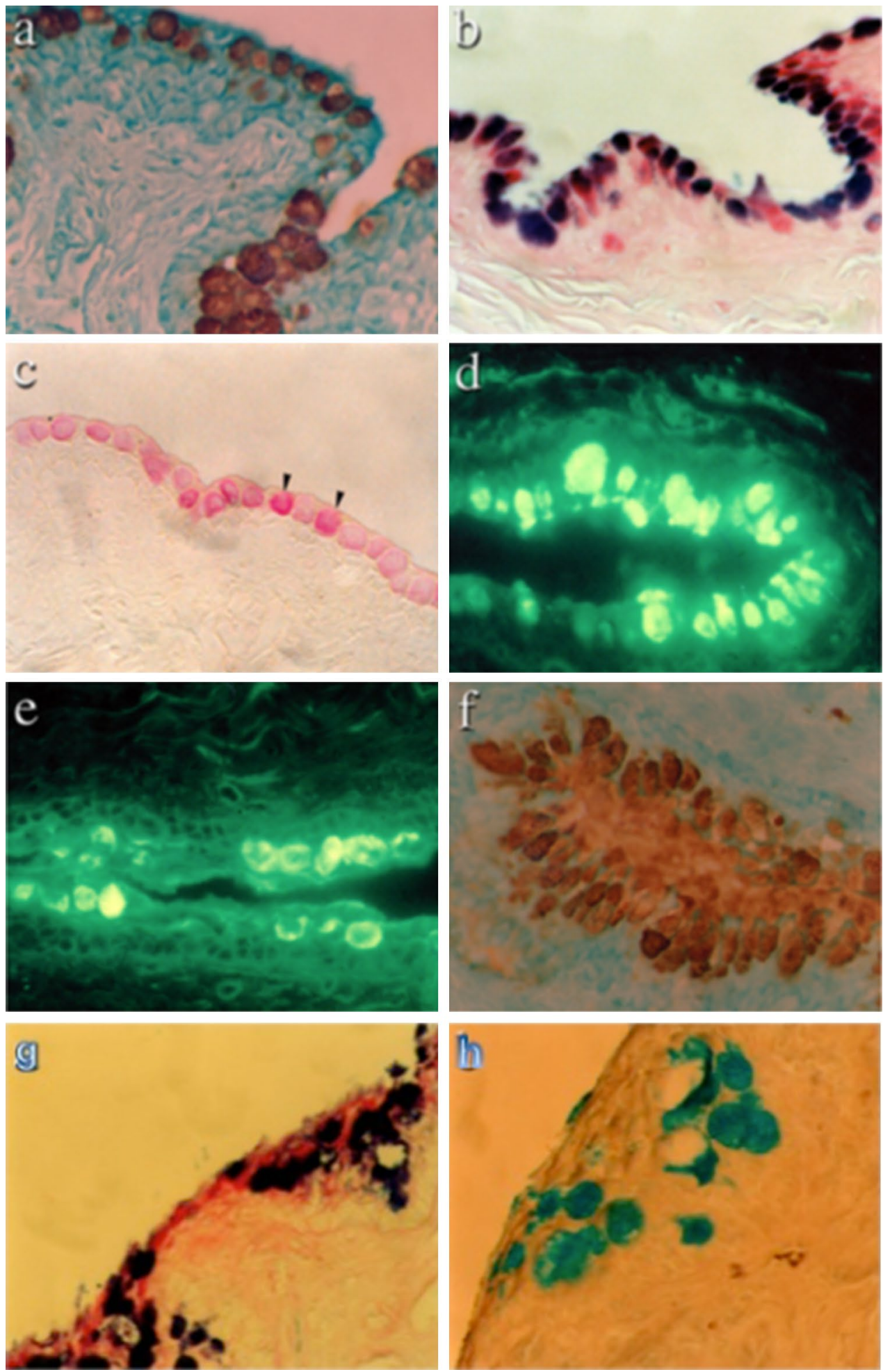

these may link with glycoprotein metabolism through interactions at mucosal surfaces throughout the body, especially in the gastrointestinal tract, as discussed above. In support of this suggestion, recent data in a mouse KO model for neuraminidase 1 (Neu1) $\mathrm{Neul}^{-1-}$ have demonstrated a role for this gene. Under normal conditions, this gene codes for an enzyme that desialylates sialoglyconjugates. This enzyme is known to regulate lysosomal exocytosis through its action on the lysosome-associated membrane protein 1 (Yogalingam et al. 2008). One function of this protein is the mediation of lysosome docking at the plasma membrane. These lysosomes then release their contents into the 
extracellular environment. This function is common to the majority of cells. In the absence of NEU1, the lysosomalassociated membrane protein 1 (LAMP-1) remains sialylated and leads to an increased number of lysosomes at the plasma membrane. As a result abnormal remodelling of the extracellular matrix and plasma membrane glycocalyx occurs (Annunziata et al. 2013). The work identifies APP as a substrate for NEU1 and rescue of the condition in $\mathrm{Neul}^{-1-}$ mice is achieved by intracranial injection of NEU1, resulting in fewer amyloid plaques (Annunziata et al. 2013). These results open the door for further examination of glycosylation in $\mathrm{AD}$ and potential therapeutic approaches.

\section{Conclusions and perspectives}

This review provides an overview of the range of glycan structures present in and utilized by the Eukaryotes. Future studies will be in the application of structural technology and bioinformatics to clarify the glycosylation of glycoproteins structurally and conformationally. This is especially important for those situations, where glycoproteins have an already clearly defined biological function and also where changes in glycosylation occur in relation to normal development, tissue function and disease. Attractive perspectives include the regulation of malignancyassociated expression of growth factors by manipulatory glycosylation (Gabius et al. 2012). Many of the advances leading to our current knowledge have come from disease situations where glycoproteins are implicated and the glycans they carry are responsible for aberrant biological behaviour. It is therefore necessary to identify the normal glycosylation patterns in order to demonstrate their significance in disease. The sites of tissue presence of glycoproteins are a fundamental part of this programme and depend on histological approaches to address this issue. The importance of lectins and antibodies is crucial in this respect (Roth 2011) and is covered further in the section on lectins in this theme issue. As implicated under "Glycosylation of proteins" above, advances in carbohydrate and supramolecular chemistry contribute to make custommade reagents available (Murphy et al. 2013; Percec et al. 2013; Zhang et al. 2015a, b; Roy et al. 2016; for a histochemical application, please see Roy et al. 2017, this issue). This is relevant for histochemistry and cell biology, where design and preparation of new molecules can support improved detection and specificity analysis.

Acknowledgement I am indebted to Gunnar Hansson (University of Gothenburg, Sweden) for sending copies of ongoing work before full publication. I am aware that the available body of evidence on this topic is not fully represented. This is due to the educational emphasis given to this review. I apologize to all those who feel left out. I am indebted to Nedim and the Staff of Pomegranate, Keynsham, Bristol, UK, for the reading space, inspirational environment and excellent coffee throughout the preparation and completion of this review.

Open Access This article is distributed under the terms of the Creative Commons Attribution 4.0 International License (http://creativecommons.org/licenses/by/4.0/), which permits unrestricted use, distribution, and reproduction in any medium, provided you give appropriate credit to the original author(s) and the source, provide a link to the Creative Commons license, and indicate if changes were made.

\section{References}

Aebi M (2013) $N$-Linked protein glycosylation in the ER. Biochim Biophys Acta 1833:2430-2437

Agawa S, Jass JR (1990) Sialic acid histochemistry and the adenomacarcinoma sequence in colorectum. J Clin Pathol 43:527-532

Albenberg LG, Lewis JD, Wu GD (2012) Food and the gut microbiota in inflammatory bowel diseases: a critical connection. Curr Opin Gastroenterol 28:314-320

Albert TK, Laubinger W, Müller S, Hanisch FG, Kalinski T, Meyer F, Hoffmann W (2010) Human intestinal TFF3 forms disulfidelinked heteromers with the mucus-associated FCGBP protein and is released by hydrogen sulfide. J Proteome Res 9:3108-3117

Alemka A, Corcionivoschi N, Bourke B (2012) Defense and adaptation: the complex inter-relationship between Campylobacter jejuni and mucus. Front Cell Infect Microbiol 2:15

Allen A, Flemström G (2005) Gastroduodenal mucus bicarbonate barrier: protection against acid and pepsin. Am J Physiol Cell Physiol 288:C1-19

Ambort D, van der Post S, Johansson ME, Mackenzie J, Thomsson E, Krengel U, Hansson GC (2011) Function of the CysD domain of the gel-forming MUC2 mucin. Biochem J 436:61-70

Ambort D, Johansson ME, Gustafsson JK, Nilsson HE, Ermund A, Johansson BR, Koeck PJ, Hebert H, Hansson GC (2012) Calcium and $\mathrm{pH}$-dependent packing and release of the gel-forming MUC2 mucin. Proc Natl Acad Sci USA 109:5645-5650

Andersch-Bjorkman Y, Thomsson KA, Holmen Larsson JM, Ekerhovd E, Hansson GC (2007) Large scale identification of proteins, mucins, and their $O$-glycosylation in the endocervical mucus during the menstrual cycle. Mol Cell Proteomics 6:708-716

André S, Unverzagt C, Kojima S, Dong X, Fink C, Kayser K, Gabius H-J (1997) Neoglycoproteins with the synthetic complex biantennary nonasaccharide or its $\alpha 2,3 / \alpha 2,6$-sialylated derivatives: their preparation, assessment of their ligand properties for purified lectins, for tumor cells in vitro, and in tissue sections, and their biodistribution in tumor-bearing mice. Bioconjug Chem 8:845-855

André S, Kozár T, Schuberth R, Unverzagt C, Kojima S, Gabius $\mathrm{H}-\mathrm{J}$ (2007) Substitutions in the $\mathrm{N}$-glycan core as regulators of biorecognition: the case of core-fucose and bisecting GlcNAc moieties. Biochemistry 46:6984-6995

André S, Kaltner H, Kayser K, Murphy PV, Gabius H-J (2016) Merging carbohydrate chemistry with lectin histochemistry to study inhibition of lectin binding by glycoclusters in the natural tissue context. Histochem Cell Biol 145:185-199

Andrianifahanana M, Moniaux N, Batra SK (2006) Regulation of mucin expression: mechanistic aspects and implications for cancer and inflammatory diseases. Biochim Biophys Acta 1765:189-222

Annunziata I, Patterson A, Helton D, Hu H, Moshiach S, Gomero E, Nixon R, d'Azzo A (2013) Lysosomal NEU1 deficiency affects amyloid precursor protein levels and amyloid- $\beta$ secretion via deregulated lysosomal exocytosis. Nat Commun 4:2734 
Apostolopoulos V, Xing PX, McKenzie IFC (1995) Antipeptide monoclonal-antibodies to intestinal mucin-3. J Gastroenterol Hepatol 10:555-561

Argüeso P (2008) Sugars: an exceptional protective coat for the ocular surface. Arch Soc Esp Oftalmol 83:287-290

Argüeso P, Gipson IK (2012) Assessing mucin expression and function in human ocular surface epithelia in vivo and in vitro. Methods Mol Biol 842:313-325

Argüeso P, Sumiyoshi M (2006) Characterization of a carbohydrate epitope defined by the monoclonal antibody H185: sialic acid $O$-acetylation on epithelial cell-surface mucins. Glycobiology 16:1219-1228

Argüeso P, Spurr-Michaud S, Tisdale A, Gipson IK (2002) Variation in the amount of $\mathrm{T}$ antigen and $\mathrm{N}$-acetyllactosamine oligosaccharides in human cervical mucus secretions with the menstrual cycle. J Clin Endocrinol Metab 87:5641-5648

Argüeso P, Spurr-Michaud S, Russo CL, Tisdale A, Gipson IK (2003) MUC16 mucin is expressed by the human ocular surface epithelia and carries the H185 carbohydrate epitope. Invest Ophthalmol Vis Sci 44:2487-2495

Argüeso P, Guzman-Aranguez A, Mantelli F, Cao Z, Ricciuto J, Panjwani N (2009) Association of cell surface mucins with galectin-3 contributes to the ocular surface epithelial barrier. J Biol Chem 284:23037-23045

Arthur JC, Jobin C (2011) The struggle within: microbial influences on colorectal cancer. Inflamm Bowel Dis 17:396-409

Artis D, Wang ML, Keilbaugh SA, He W, Brenes M, Swain GP, Knight PA, Donaldson DD, Lazar MA, Miller HRP, Schad GA, Scott P, Wu GD (2004) RELM $\beta /$ FIZZ2 is a goblet cell-specific immune-effector molecule in the gastrointestinal tract. Proc Natl Acad Sci USA 101:13596-13600

Aryal RP, Ju T, Cummings RD (2010) The endoplasmic reticulum chaperone Cosmc directly promotes in vitro folding of T-synthase. J Biol Chem 285:2456-2462

Ashwell G, Morell AG (1974) The role of surface carbohydrates in the hepatic recognition and transport of circulating glycoproteins. Adv Enzymol Relat Areas Mol Biol 41:99-128

Atuma C, Strugala V, Allen A, Holm L (2001) The adherent gastrointestinal mucus gel layer: thickness and physical state in vivo. Am J Physiol Gastrointest Liver Physiol 280:G922-G929

Aubert S, Fauquette V, Hemon B, Lepoivre R, Briez N, Bernard D, Van Seuningen I, Leroy X, Perrais M (2009) MUC1, a new hypoxia inducible factor target gene, is an actor in clear renal cell carcinoma tumor progression. Cancer Res 69:5707-5715

Audié JP, Janin A, Porchet N, Copin MC, Gosselin B, Aubert JP (1993) Expression of human mucin genes in respiratory, digestive and reproductive tracts ascertained by in situ hybridization. J Histochem Cytochem 41:1479-1485

Bäckhed F, Söderhäll M, Ekman P, Normark S, Richter-Dahlfors A (2001) Induction of innate immune responses by Escherichia coli and purified lipopolysaccharide correlate with organ- and cell-specific expression of Toll-like receptors within the human urinary tract. Cell Microbiol 3:153-158

Bäckhed F, Ley RE, Sonnenburg JL, Peterson DA, Gordon JI (2005) Host-bacterial mutualism in the human intestine. Science 307:1915-1920

Bafna S, Kaur S, Batra SK (2010) Membrane-bound mucins: the mechanistic basis for alterations in the growth and survival of cancer cells. Oncogene 29:2893-2904

Baldus SE, Zirbes TK, Hanisch FG, Kunze D, Shafizadeh ST, Nolden S, Mönig SP, Schneider PM, Karsten U, Thiele J, Hölscher AH, Dienes HP (2000) Thomsen-Friedenreich antigen presents as a prognostic factor in colorectal carcinoma: a clinicopathologic study of 264 patients. Cancer 88:1536-1543
Baos SC, Phillips DB, Wildling L, McMaster TJ, Berry M (2012) Distribution of sialic acids on mucins and gels: a defense mechanism. Biophys J 102:176-184

Bartman AE, Sanderson SJ, Ewing SL, Niehans GA, Wiehr CL, Evans MK, Ho SB (1999) Aberrant expression of MUC5AC and MUC6 gastric mucin genes in colorectal polyps. Int J Cancer 80:210-218

Baskin JM, Dehnert KW, Laughlin ST, Amacher SL, Bertozzi CR (2010) Visualizing enveloping layer glycans during zebrafish early embryogenesis. Proc Natl Acad Sci USA 107:10360-10365

Bassaganas S, Perez-Garay M, Peracaula R (2014) Cell surface sialic acid modulates extracellular matrix adhesion and migration in pancreatic adenocarcinoma cells. Pancreas 43:109-117

Bastholm SK, Samson MH, Becher N, Hansen LK, Stubbe PR, Chronakis IS, Nexo E, Uldbjerg N (2016) Trefoil factor peptide 3 is positively correlated with the viscoelastic properties of the cervical mucus plug. Acta Obstet Gynecol Scand. doi:10.1111/ aogs. 13038

Beatson R, Tajadura-Ortega V, Achkova D, Picco G, Tsourouktsoglou T-D, Klausing S, Hillier M, Maher J, Noll T, Crocker PR, Taylor-Papadimitriou J, Burchell JM (2016) The mucin MUC1 modulates the tumor immunological microenvironment through engagement of the lectin Siglec-9. Nat Immunol 17:1273-1281

Becher N, Adams Waldorf K, Hein M, Uldbjerg N (2009) The cervical mucus plug: structured review of the literature. Acta Obstet Gynecol Scand 88:502-513

Becher N, Hein M, Danielsen CC, Uldbjerg N (2010) Matrix metalloproteinases in the cervical mucus plug in relation to gestational age, plug compartment, and preterm labor. Reprod Biol Endocrinol 8:113

Bennett EP, Mandel U, Clausen H, Gerken TA, Fritz TA, Tabak LA (2012) Control of mucin-type $O$-glycosylation: a classification of the polypeptide GalNAc-transferase gene family. Glycobiology 22:736-756

Bergström JH, Birchenough GMH, Katona G, Schroeder BO, Schütte A, Ermund A, Johansson MEV, Hansson GC (2016) Gram-positive bacteria are held at a distance in the colon mucus by the lectin-like protein ZG16. Proc Natl Acad Sci USA. doi:10.1073/ pnas. 1611400113

Berry M, Ellingham RB, Corfield AP (1996) Polydispersity of normal human conjunctival mucins. Invest Ophthalmol Vis Sci 37:2559-2571

Berry M, Corfield AP, McMaster TJ (2013) Mucins: a dynamic biology. Soft Matter 9:1740-1743

Bertozzi CR, Rabuka D (2009) Structural Basis of Glycan Diversity. In: Varki A, Cummings RD, Esko JD et al (eds) Essentials of glycobiology. Cold Spring Harbor Laboratory Press, New York, pp 23-36

Bevins CL (2004) The Paneth cell and the innate immune response. Curr Opin Gastroenterol 20:572-580

Bevins CL, Salzman NH (2011) Paneth cells, antimicrobial peptides and maintenance of intestinal homeostasis. Nat Rev Microbiol 9:356-368

Bezencon C, Fürholz A, Raymond F, Mansourian R, Metairon S, Le Coutre J, Damak S (2008) Murine intestinal cells expressing Trpm5 are mostly brush cells and express markers of neuronal and inflammatory cells. J Comp Neurol 509:514-525

Bhide GP, Colley KJ (2017) Sialylation of $N$-glycans: mechanism, cellular compartmentalization and function. Histochem Cell Biol 147(2). doi:10.1007/s00418-016-1520-x

Birchenough GM, Johansson ME, Gustafsson JK, Bergström JH, Hansson GC (2015) New developments in goblet cell mucus secretion and function. Mucosal Immunol 8:712-719 
Birchenough GM, Nyström EE, Johansson ME, Hansson GC (2016) A sentinel goblet cell guards the colonic crypt by triggering Nlrp6-dependent Muc2 secretion. Science 352:1535-1542

Bonfanti L, Theodosis DT (2009) Polysialic acid and activity-dependent synapse remodeling. Cell Adh Migr 3:43-50

Breitling J, Aebi M (2013) N-Linked protein glycosylation in the endoplasmic reticulum. Cold Spring Harb Perspect Biol 5:a013359

Brockhausen I (2003) Glycodynamics of mucin biosynthesis in gastrointestinal tumor cells. Adv Exp Med Biol 535:163-188

Brockhausen I (2006) The role of galactosyltransferases in cell surface functions and in the immune system. Drug News Perspect 19:401-409

Brockhausen I, Schachter H (1997) Glycosyltransferases involved in $N$ - and $O$-glycan biosynthesis. In: Gabius H-J, Gabius S (eds) Glycosciences: status and perspectives. Chapman \& Hall, Weinheim, pp 79-113

Brockhausen I, Carver JP, Schachter H (1988) Control of glycoprotein synthesis. The use of oligosaccharide substrates and HPLC to study the sequential pathway for $\mathrm{N}$-acetylglucosaminyltransferases I, II, III, IV, V, and VI in the biosynthesis of highly branched $N$-glycans by hen oviduct membranes. Biochem Cell Biol 66:1134-1151

Brockhausen I, Yang J, Dickinson N, Ogata S, Itzkowitz SH (1998) Enzymatic basis for sialyl-Tn expression in human colon cancer cells. Glycoconj J 15:595-603

Buddecke E (2009) Proteoglycans. In: Gabius H-J (ed) The sugar code. Fundamentals of glycosciences. Wiley-VCH, Weinheim, pp 199-216

Buisine M-P, Janin A, Mauroury V, Audie J-P, Delescaut M-P, Copin M-C, Colombel J-F, Degand P, Aubert J-P, Porchet N (1996) Abberant expression of a human mucin gene (MUC5AC) in rectosigmoid villous adenoma. Gastroenterology 110:84-91

Buisine M-P, Devisme L, Copin MC, Durand-Reville M, Gosselin B, Aubert JP, Porchet N (1999) Developmental mucin gene expression in the human respiratory tract. Am J Respir Cell Mol Biol 20:209-218

Buisine M-P, Devisme L, Degand P, Dieu MC, Gosselin B, Copin MC, Aubert JP, Porchet N (2000) Developmental mucin gene expression in the gastroduodenal tract and accessory digestive glands. II. Duodenum and liver, gallbladder, and pancreas. J Histochem Cytochem 48:1667-1676

Buisine M-P, Desreumaux P, Leteurtre E, Copin MC, Colombel JF, Porchet N, Aubert JP (2001) Mucin gene expression in intestinal epithelial cells in Crohn's disease. Gut 49:544-551

Buk SJ, Filipe MI (1986) Histochemical staining of sulphated and non-sulphated sialomucin in intestinal epithelium: practical difficulties associated with the KOH-AB 1.0-PAPS method. Histochem J 18:576-578

Bull C, den Brok MH, Adema GJ (2014) Sweet escape: sialic acids in tumor immune evasion. Biochim Biophys Acta 1846:238-246

Butkinaree C, Park K, Hart GW (2010) O-Linked $\beta-N$ acetylglucosamine $(O-G l c N A c)$ : extensive crosstalk with phosphorylation to regulate signaling and transcription in response to nutrients and stress. Biochim Biophys Acta 1800:96-106

Campbell BJ, Yu LG, Rhodes JM (2001) Altered glycosylation in inflammatory bowel disease: a possible role in cancer development. Glycoconj J 18:851-858

Candela M, Guidotti M, Fabbri A, Brigidi P, Franceschi C, Fiorentini C (2011) Human intestinal microbiota: cross-talk with the host and its potential role in colorectal cancer. Crit Rev Microbiol 37:1-14

Carrington SD, Hicks SJ, Corfield AP, Kaswan RL, Packer N, Bolis S, Morris CA (1998) Structural analysis of secreted ocular mucins in canine dry eye. Adv Exp Med Biol 438:253-263
Charest PM, Roth J (1988) Localization of sialic acid in kidney glomeruli: regionalization in the podocyte plasma membrane and loss in experimental nephrosis. Proc Natl Acad Sci USA 82:8508-8512

Chen Y, Zhao YH, Kalaslavadi TB, Hamati E, Nehrke K, Le AD, Ann DK, Wu R (2004) Genome-wide search and identification of a novel gel-forming mucin MUC19/Muc19 in glandular tissues. Am J Respir Cell Mol Biol 30:155-165

Chen C, Constantinou A, Chester KA, Vyas B, Canis K, Haslam SM, Dell A, Epenetos AA, Deonarain MP (2012) Glycoengineering approach to half-life extension of recombinant biotherapeutics. Bioconjug Chem 23:1524-1533

Clevers HC, Bevins CL (2013) Paneth cells: maestros of the small intestinal crypts. Annu Rev Physiol 75:289-311

Copin MC, Devisme L, Buisine MP, Marquette CH, Wurtz A, Aubert JP, Gosselin B, Porchet N (2000) From normal respiratory mucosa to epidermoid carcinoma: expression of human mucin genes. Int J Cancer 86:162-168

Corfield T (2011) The mucosal barrier. Protective frontier to the outside world. Biochemistry 33:10-15

Corfield AP (2015) Mucins: a biologically relevant glycan barrier in mucosal protection. Biochim Biophys Acta 1850:236-252

Corfield AP, Berry M (2015) Glycan variation and evolution in the eukaryotes. Trends Biochem Sci 40:351-359

Corfield AP, Warren BF (1996) The modern investigation of mucus glycoproteins and their role in gastrointestinal disease. J Pathol 180:8-17

Corfield AP, Wagner SA, Paraskeva C, Clamp JR, Durdey P, Reuter G, Schauer R (1992a) Loss of sialic acid $O$-acetylation in human colorectal cancer cells. Biochem Soc Trans 20:94S

Corfield AP, Warren BF, Bartolo DC, Wagner SA, Clamp JR (1992b) Mucin changes in ileoanal pouches monitored by metabolic labelling and histochemistry. Br J Surg 79:1209-1212

Corfield AP, Myerscough N, Bradfield N, Corfield Cdo A, Gough M, Clamp JR, Durdey P, Warren BF, Bartolo DC, King KR, Williams JM (1996) Colonic mucins in ulcerative colitis: evidence for loss of sulfation. Glycoconj J 13:809-822

Corfield AP, Myerscough N, Warren BF, Durdey P, Paraskeva C, Schauer R (1999) Reduction of sialic acid $O$-acetylation in human colonic mucins in the adenoma-carcinoma sequence. Glycoconj J 16:307-317

Corfield AP, Donapaty SR, Carrington SD, Hicks SJ, Schauer R, Kohla $\mathrm{G}$ (2005) Identification of 9-O-acetyl- $\mathrm{N}$-acetylneuraminic acid in normal canine pre-ocular tear film secreted mucins and its depletion in Keratoconjunctivitis sicca. Glycoconj J 22:409-416

Corfield AP, Wallace HM, Probert CS (2011) The molecular biology of inflammatory bowel diseases. Biochem Soc Trans 39:1057-1060

Crocker PR (2005) Siglecs in innate immunity. Curr Opin Pharmacol 5:431-437

Crocker PR, Paulson JC, Varki A (2007) Siglecs and their roles in the immune system. Nat Rev Immunol 7:255-266

Croix JA, Carbonero F, Nava GM, Russell M, Greenberg E, Gaskins HR (2011) On the relationship between sialomucin and sulfomucin expression and hydrogenotrophic microbes in the human colonic mucosa. PLoS ONE 6:e24447

Dalal SR, Chang EB (2014) The microbial basis of inflammatory bowel diseases. J Clin Invest 124:4190-4196

Dall'Olio F, Malagolini N, di Stefano G, Minni F, Marrano D, SerafiniCessi F (1989) Increased CMP-NeuAc:Gal $\beta 1,4$ GlcNAc-R $\alpha 2,6$ sialyltransferase activity in human colorectal cancer tissues. Int J Cancer 44:434-439

Dall'Olio F, Malagolini N, Trinchera M, Chiricolo M (2014) Sialosignaling: sialyltransferases as engines of self-fueling loops in cancer progression. Biochim Biophys Acta 1840:2752-2764 
Damman CJ, Miller SI, Surawicz CM, Zisman TL (2012) The microbiome and inflammatory bowel disease: is there a therapeutic role for fecal microbiota transplantation? Am J Gastroenterol 107:1452-1459

Davies JR, Wickstrom C, Thornton DJ (2012) Gel-forming and cellassociated mucins: preparation for structural and functional studies. Methods Mol Biol 842:27-47

D'Cruz OJ, Dunn TS, Pichan P, Hass GG Jr, Sachdev GP (1996) Antigenic cross-reactivity of human tracheal mucin with human sperm and trophoblasts correlates with the expression of mucin 8 gene messenger ribonucleic acid in reproductive tract tissues. Fertil Steril 66:316-326

Dell A, Morris HR, Easton RL, Panico M, Patankar M, Oehniger S, Koistinen R, Koistinen H, Seppala M, Clark GF (1995) Structural analysis of the oligosaccharides derived from glycodelin, a human glycoprotein with potent immunosuppressive and contraceptive activities. J Biol Chem 270:24116-24126

Dell A, Galadari A, Sastre F, Hitchen P (2010) Similarities and differences in the glycosylation mechanisms in prokaryotes and eukaryotes. Int J Microbiol 2010:148178

DeSouza MM, Lagow E, Carson DD (1998) Mucin functions and expression in mammalian reproductive tract tissues. Biochem Biophys Res Commun 247:1-6

Desseyn JL (2009) Mucin CYS domains are ancient and highly conserved modules that evolved in concert. Mol Phylogenet Evol 52:284-292

Desseyn JL, Gouyer V, Gottrand F (2016) Biological modeling of mucus to modulate mucus barriers. Am J Physiol Gastrointest Liver Physiol 310:G225-G227

Diekman AB (2003) Glycoconjugates in sperm function and gamete interactions: how much sugar does it take to sweet-talk the egg? Cell Mol Life Sci 60:298-308

Ebong EE, Macaluso FP, Spray DC, Tarbell JM (2011) Imaging the endothelial glycocalyx in vitro by rapid freezing/freeze substitution transmission electron microscopy. Arterioscler Thromb Vasc Biol 31:1908-1915

Ermund A, Gustafsson JK, Hansson GC, Keita AV (2013a) Mucus properties and goblet cell quantification in mouse, rat and human ileal Peyer's patches. PLoS ONE 8:e83688

Ermund A, Schütte A, Johansson ME, Gustafsson JK, Hansson GC (2013b) Studies of mucus in mouse stomach, small intestine, and colon. I. Gastrointestinal mucus layers have different properties depending on location as well as over the Peyer's patches. Am J Physiol Gastrointest Liver Physiol 305:G341-G347

Etzler ME, Mohnen D (2009) Viridiplantae. In: Varki A, Cummings RD, Esko JD et al (eds) Essentials of glycobiology. Cold Spring Harbor, New York, pp 321-332

Falagas M, Betsi GI, Athanasiou S (2007) Probiotics for the treatment of women with bacterial vaginosis. Clin Microbiol Infect 13:657-664

Fava F, Danese S (2011) Intestinal microbiota in inflammatory bowel disease: friend of foe? World J Gastroenterol 17:557-566

Ferguson MAJ, Kinoshita T, Hart GW (2009) Glycosylphosphatidylinositol anchors. In: Varki A, Cummings RD, Esko JD et al (eds) Essentials of glycobiology. Cold Spring Harbor, New York, pp 143-161

Filipe MI, Branfoot AC (1983) Mucin histochemistry of the colon. In: Morson BC (ed) Current topics in pathology. Springer, Heidelberg, pp 143-178

Filipe IM, Ramachandra S (1995) The histochemistry of intestinal mucins; changes in disease. In: Whitehead R (ed) Gastrointestinal and oesophageal pathology. Churchill Livingstone, Edinburgh, pp 73-95

Flejou JF (2005) Barrett's oesophagus: from metaplasia to dysplasia and cancer. Gut 54(Suppl 1):i6-12
Franke FE, Kraus S, Eiermann C, Pauls K, Lalani EN, Bergmann M (2001) MUC1 in normal and impaired spermatogenesis. Mol Hum Reprod 7:505-512

Gabius H-J (1997) Animal lectins. Eur J Biochem 243:543-576

Gabius H-J (ed) (2009) The sugar code. Fundamentals of glycosciences. Wiley-VCH, Weinheim

Gabius H-J (2015) The magic of the sugar code. Trends Biochem Sci 40:341

Gabius H-J, Roth J (2017) An introduction to the sugar code. Histochem Cell Biol 147(2). doi:10.1007/s00418-016-1521-9

Gabius H-J, André S, Jiménez-Barbero J, Romero A, Solís D (2011) From lectin structure to functional glycomics: principles of the sugar code. Trends Biochem Sci 36:298-313

Gabius H-J, van de Wouwer M, André S, Villalobo A (2012) Downregulation of the epidermal growth factor receptor by altering $N$-glycosylation: emerging role of $\beta 1,4$-galactosyltransferases. Anticancer Res 32:1565-1572

Gabius H-J, Kaltner H, Kopitz J, André S (2015) The glycobiology of the CD system: a dictionary for translating marker designations into glycan/lectin structure and function. Trends Biochem Sci 40:360-376

Gabius H-J, Manning JC, Kopitz J, André S, Kaltner H (2016) Sweet complementarity: the functional pairing of glycans with lectins. Cell Mol Life Sci 73:1989-2016

Garcher C, Bron A, Baudouin C, Bildstein L, Bara J (1998) CA 19-9 ELISA test: a new method for studying mucus changes in tears. Br J Ophthalmol 82:88-90

Gebauer JM, Müller S, Hanisch FG, Paulsson M, Wagener R (2008) $O$-glucosylation and $O$-fucosylation occur together in close proximity on the first epidermal growth factor repeat of AMACO (VWA2 protein). J Biol Chem 283:17846-17854

Gebhard A, Gebert A (1999) Brush cells of the mouse intestine possess a specialized glycocalyx as revealed by quantitative lectin histochemistry. Further evidence for a sensory function. J Histochem Cytochem 47:799-808

Gentschew L, Ferguson LR (2012) Role of nutrition and microbiota in susceptibility to inflammatory bowel diseases. Mol Nutr Food Res 56:524-535

Gerbe F, Jay P (2016) Intestinal tuft cells: epithelial sentinels linking luminal cues to the immune system. Mucosal Immunol 9:1353-1359

Gerken TA, Ten Hagen KG, Jamison O (2008) Conservation of peptide acceptor preferences between Drosophila and mammalian polypeptide-GalNAc transferase ortholog pairs. Glycobiology 18:861-870

Gerken TA, Jamison O, Perrine CL, Collette JC, Moinova H, Ravi L, Markowitz SD, Shen W, Patel H, Tabak LA (2011) Emerging paradigms for the initiation of mucin-type protein $O$-glycosylation by the polypeptide GalNAc transferase family of glycosyltransferases. J Biol Chem 286:14493-14507

Gerken TA, Revoredo L, Thome JJ, Tabak LA, Vester-Christensen MB, Clausen H, Gahlay GK, Jarvis DL, Johnson RW, Moniz HA, Moremen K (2013) The lectin domain of the polypeptide GalNAc transferase family of glycosyltransferases (ppGalNAc Ts) acts as a switch directing glycopeptide substrate glycosylation in an $\mathrm{N}$ - or $\mathrm{C}$-terminal direction, further controlling mucin type $O$-glycosylation. J Biol Chem 288:19900-19914

Gipson IK (2001) Mucins of the human endocervix. Front Biosci 6:D1245-D1255

Gipson IK (2004) Distribution of mucins at the ocular surface. Exp Eye Res 78:379-388

Gipson IK (2005) Human endocervical mucins. Ernst Schering Research Foundation workshop, pp 219-244

Gipson IK (2007) The ocular surface: the challenge to enable and protect vision: the Friedenwald lecture. Invest Ophthalmol Vis Sci 48:4391-4398 
Gipson IK, Argüeso P (2003) Role of mucins in the function of the corneal and conjunctival epithelia. Int Rev Cytol 231:1-49

Gipson IK, Inatomi T (1998) Cellular origin of mucins of the ocular surface tear film. Adv Exp Med Biol 438:221-227

Gipson IK, Spurr-Michaud S, Moccia R, Zhan Q, Toribara N, Ho SB, Gargiulo AR, Hill JA 3rd (1999) MUC4 and MUC5B transcripts are the prevalent mucin messenger ribonucleic acids of the human endocervix. Biol Reprod 60:58-64

Gipson IK, Moccia R, Spurr-Michaud S, Argueso P, Gargiulo AR, Hill JA 3rd, Offner GD, Keutmann HT (2001) The amount of MUC5B mucin in cervical mucus peaks at midcycle. J Clin Endocrinol Metab 86:594-600

Gipson IK, Hori Y, Argüeso P (2004) Character of ocular surface mucins and their alteration in dry eye disease. Ocul Surf 2:131-148

Gipson IK, Blalock T, Tisdale A, Spurr-Michaud S, Allcorn S, Stavreus-Evers A, Gemzell K (2008) MUC16 is lost from the uterodome (pinopode) surface of the receptive human endometrium: in vitro evidence that MUC16 is a barrier to trophoblast adherence. Biol Reprod 78:134-142

Gouyer V, Dubuquoy L, Robbe-Masselot C, Neut C, Singer E, Plet S, Geboes K, Desreumaux P, Gottrand F, Desseyn JL (2015) Delivery of a mucin domain enriched in cysteine residues strengthens the intestinal mucous barrier. Sci Rep 5:9577

Govindarajan B, Gipson IK (2010) Membrane-tethered mucins have multiple functions on the ocular surface. Exp Eye Res 90:655-663

Grabowski P, Mann B, Mansmann U, Lövin N, Foss HD, Berger G, Scherübl H, Riecken EO, Buhr HJ, Hanski C (2000) Expression of SIALYL-Le(x) antigen defined by MAb AM-3 is an independent prognostic marker in colorectal carcinoma patients. Int J Cancer 88:281-286

Gustafsson JK, Ermund A, Johansson ME, Schütte A, Hansson GC, Sjövall H (2012) An ex vivo method for studying mucus formation, properties, and thickness in human colonic biopsies and mouse small and large intestinal explants. Am J Physiol Gastrointest Liver Physiol 302:G430-G438

Guzman-Aranguez A, Mantelli F, Argüeso P (2009) Mucin-type $O$-glycans in tears of normal subjects and patients with nonSjogren's dry eye. Invest Ophthalmol Vis Sci 50:4581-4587

Habermann FA, Sinowatz F (2009) Glycobiology of fertilization and early embryonic development. In: Gabius H-J (ed) The sugar code. Fundamentals of glycosciences. Wiley-VCH, Weinheim, pp 403-417

Habermann FA, André S, Kaltner H, Kübler D, Sinowatz F, Gabius H-J (2011) Galectins as tools for glycan mapping in histology: comparison of their binding profiles to the bovine zona pellucida by confocal laser scanning microscopy. Histochem Cell Biol 135:539-552

Habte HH, de Beer C, Lotz ZE, Tyler MG, Schoeman L, Kahn D, Mall AS (2008) The inhibition of the Human Immunodeficiency Virus type 1 activity by crude and purified human pregnancy plug mucus and mucins in an inhibition assay. Virol J 5:59

Hajishengallis G, Darveau RP, Curtis MA (2012) The keystone-pathogen hypothesis. Nat Rev Microbiol 10:717-725

Hänsch M, Simon P, Schön J, Kaese M, Braun BC, Jewgenow K, Göritz F, Küpper J, Ahmadvand N, Geyer R, Middendorff R, Müller K, Galuska SP (2014) Polysialylation of NCAM correlates with onset and termination of seasonal spermatogenesis in roe deer. Glycobiology 24:488-493

Hansen LK, Becher N, Bastholm S, Glavind J, Ramsing M, Kim CJ, Romero R, Jensen JS, Uldbjerg N (2014) The cervical mucus plug inhibits, but does not block, the passage of ascending bacteria from the vagina during pregnancy. Acta Obstet Gynecol Scand 93:102-108
Hanski C, Hanski M-L, Zimmer T, Ogorek D, Devine P, Riecken E-O (1995) Characterization of the major sialyl-Le ${ }^{\mathrm{x}}$-positive mucins present in colon, colon carcinoma, and sera of patients with colorectal cancer. Cancer Res 55:928-933

Hart GW, Copeland RJ (2010) Glycomics hits the big time. Cell 143:672-676

Hasnain SZ, Gallagher AL, Grencis RK, Thornton DJ (2013) A new role for mucins in immunity: insights from gastrointestinal nematode infection. Int J Biochem Cell Biol 45:364-374

Hattrup CL, Gendler SJ (2008) Structure and function of the cell surface (tethered) mucins. Annu Rev Physiol 70:431-457

He W, Wang ML, Jiang HQ, Steppan CM, Shin ME, Thurnheer MC, Cebra JJ, Lazar MA, Wu GD (2003) Bacterial colonization leads to the colonic secretion of RELM $\beta / F I Z Z 2$, a novel goblet cell-specific protein. Gastroenterology 125:1388-1397

Hein M, Petersen AC, Helmig RB, Uldbjerg N, Reinholdt J (2005) Immunoglobulin levels and phagocytes in the cervical mucus plug at term of pregnancy. Acta Obstet Gynecol Scand 84:734-742

Helenius A (2001) Quality control in the secretory assembly line. Philos Trans R Soc Lond B Biol Sci 356:147-150

Helenius A, Trombetta ES, Hebert DN, Simons JF (1997) Calnexin, calreticulin and the folding of glycoproteins. Trends Cell Biol 7:193-200

Hennet T (2009) Diseases of glycosylation. In: Gabius H-J (ed) The sugar code. Fundamentals of glycosciences. Wiley-VCH, Weinheim, pp 365-383

Hennet T, Cabalzar J (2015) Congenital disorders of glycosylation: a concise chart of glycocalyx dysfunction. Trends Biochem Sci 40:377-384

Higuchi T, Orita T, Nakanishi S, Katsuya K, Watanabe H, Yamasaki Y, Waga I, Nanayama T, Yamamoto Y, Munger W, Sun HW, Falk RJ, Jennette JC, Alcorta DA, Li H, Yamamoto T, Saito Y, Nakamura M (2004) Molecular cloning, genomic structure, and expression analysis of MUC20, a novel mucin protein, up-regulated in injured kidney. J Biol Chem 279:1968-1979

Higuero AM, Díez-Revuelta N, Abad-Rodríguez J (2017) The sugar code in neuronal physiology. Histochem Cell Biol 147(2). doi:10.1007/s00418-016-1519-3

Hildebrandt H, Mühlenhoff M, Weinhold B, Gerardy-Schahn R (2007) Dissecting polysialic acid and NCAM functions in brain development. J Neurochem 103(Suppl 1):56-64

Hodges RR, Dartt DA (2013) Tear film mucins: front line defenders of the ocular surface; comparison with airway and gastrointestinal tract mucins. Exp Eye Res 117:62-78

Hoffmann W (2004) Trefoil factor family (TFF) peptides: regulators of mucosal regeneration and repair, and more. Peptides 25:727-730

Hofsteenge J, Müller DR, de Beer T, Löffler A, Richter WJ, Vliegenthart JF (1994) New type of linkage between a carbohydrate and a protein: $C$-glycosylation of a specific tryptophan residue in human RNase Us. Biochemistry 33:13524-13530

Hofsteenge J, Huwiler KG, Macek B, Hess D, Lawler J, Mosher DF, Peter-Katalinic J (2001) $C$-Mannosylation and $O$-fucosylation of the thrombospondin type 1 module. J Biol Chem 276:6485-6498

Holmén Larsson JM, Thomsson KA, Rodríguez-Piñeiro AM, Karlsson H, Hansson GC (2013) Studies of mucus in mouse stomach, small intestine, and colon. III. Gastrointestinal Muc5ac and Muc2 mucin $O$-glycan patterns reveal a regiospecific distribution. Am J Physiol Gastrointest Liver Physiol 305:G357-G363

Holmén JM, Karlsson NG, Abdullah LH, Randell SH, Sheehan JK, Hansson GC, Davis CW (2004) Mucins and their $O$-glycans from human bronchial epithelial cell cultures. Am J Physiol Lung Cell Mol Physiol 287:L824-L834 
Hooper LV, Littman DR, Macpherson AJ (2012) Interactions between the microbiota and the immune system. Science 336:1268-1273

Howitt MR, Lavoie S, Michaud M, Blum AM, Tran SV, Weinstock JV, Gallini CA, Redding K, Margolskee RF, Osborne LC, Artis D, Garrett WS (2016) Tuft cells, taste-chemosensory cells, orchestrate parasite type 2 immunity in the gut. Science 351:1319-1333

Huang ML, Godula K (2016) Nanoscale materials for probing the biological functions of the glycocalyx. Glycobiology 26:797-803

Huet G, Gouyer V, Delacour D, Richet C, Zanetta JP, Delannoy P, Degand P (2003) Involvement of glycosylation in the intracellular trafficking of glycoproteins in polarized epithelial cells. Biochimie 85:323-330

Hunt PN, Wilson MD, von Schalburg KR, Davidson WS, Koop BF (2005) Expression and genomic organization of zonadhesin-like genes in three species of fish give insight into the evolutionary history of a mosaic protein. BMC Genomics 6:165

Itzkowitz SH, Bloom EJ, Kokal WA, Modin G, S-i Hakomori, Kim YS (1990) Sialosyl-Tn: a novel mucin antigen associated with prognosis in colorectal cancer patients. Cancer 66:1960-1966

Iwai T, Kudo T, Kawamoto R, Kubota T, Togayachi A, Hiruma T, Okada T, Kawamoto T, Morozumi K, Narimatsu H (2005) Core 3 synthase is down-regulated in colon carcinoma and profoundly suppresses the metastatic potential of carcinoma cells. Proc Natl Acad Sci USA 102:4572-4577

Jansen RPS (1995) Ultrastructure and histochemistry of acid mucus glycoproteins in the estrous mammal oviduct. Microsc Res Tech 32:29-49

Jass JR, Allison LJ, Edgar SG (1995) Distribution of sialosyl-Tn and Tn antigens within normal and malignant colorectal epithelium. J Pathol 176:143-149

Jayachandran R, Radcliffe CM, Royle L, Harvey DJ, Dwek RA, Rudd PM, Karande AA (2006) Oligosaccharides modulate the apoptotic activity of glycodelin. Glycobiology 16:1052-1063

Jee BK, Lee JY, Lim Y, Lee KH, Jo YH (2007) Effect of KAI1/CD82 on the $\beta 1$ integrin maturation in highly migratory carcinoma cells. Biochem Biophys Res Commun 359:703-708

Johansson ME, Hansson GC (2012) Analysis of assembly of secreted mucins. Methods Mol Biol 842:109-121

Johansson ME, Hansson GC (2013) Mucus and the goblet cell. Dig Dis 31:305-309

Johansson ME, Hansson GC (2016) Immunological aspects of intestinal mucus and mucins. Nat Rev Immunol 16:639-649

Johansson ME, Phillipson M, Petersson J, Velcich A, Holm L, Hansson GC (2008) The inner of the two Muc2 mucin-dependent mucus layers in colon is devoid of bacteria. Proc Natl Acad Sci USA 105:15064-15069

Johansson ME, Sjovall H, Hansson GC (2013) The gastrointestinal mucus system in health and disease. Nat Rev Gastroenterol Hepatol 10:352-361

Kaltner H, Toegel S, García Caballero G, Manning JC, Ledeen RW, Gabius H-J (2017) Galectins: their network and roles in immunity/tumor growth control. Histochem Cell Biol 147(2). doi:10.1007/s00418-016-1522-8

Kesimer M, Ehre C, Burns KA, Davis CW, Sheehan JK, Pickles RJ (2013) Molecular organization of the mucins and glycocalyx underlying mucus transport over mucosal surfaces of the airways. Mucosal Immunol 6:379-392

King MJ, Chan A, Roe R, Warren BF, Dell A, Morris HR, Bartolo DC, Durdey P, Corfield AP (1994) Two different glycosyltransferase defects that result in GalNAc $\alpha$-O-peptide (Tn) expression. Glycobiology 4:267-279

Kirkham S, Sheehan JK, Knight D, Richardson PS, Thornton DJ (2002) Heterogeneity of airways mucus: variations in the amounts and glycoforms of the major oligomeric mucins MUC5AC and MUC5B. Biochem J 361:537-546
Klisch K, Contreras DA, Sun X, Brehm R, Bergmann M, Alberio $\mathrm{R}$ (2011) The Sda/GM2-glycan is a carbohydrate marker of porcine primordial germ cells and of a subpopulation of spermatogonia in cattle, pigs, horses and llama. Reproduction 142:667-674

Knight P, Campbell BJ, Rhodes JM (2008) Host-bacteria interaction in inflammatory bowel disease. Br Med Bull 88:95-113

Kocer B, Soran A, Erdogan S, Karabeyoglu M, Yildirim O, Eroglu A, Bozkurt B, Cengiz O (2002) Expression of MUC5AC in colorectal carcinoma and relationship with prognosis. Pathol Int $52: 470-477$

Koistinen H, Easton RL, Chiu PC, Chalabi S, Halttunen M, Dell A, Morris HR, Yeung WS, Seppala M, Koistinen R (2003) Differences in glycosylation and sperm-egg binding inhibition of pregnancy-related glycodelin. Biol Reprod 69:1545-1551

Kolarich D, Lepenies B, Seeberger PH (2012) Glycomics, glycoproteomics and the immune system. Curr Opin Chem Biol $16: 214-220$

Kopitz J (2017) Lipid glycosylation: a primer for histochemists and cell biologists. Histochem Cell Biol 147(2). doi:10.1007/ s00418-016-1518-4

Kornfeld S, Reitman ML, Varki A, Goldberg D, Gabel CA (1982) Steps in the phosphorylation of the high mannose oligosaccharides of lysosomal enzymes. Ciba Found Symp (92):138-156

Kozak RP, Urbanowicz PA, Punyadeera C, Reiding KR, Jansen BC, Royle L, Spencer DI, Fernandes DL, Wuhrer M (2016) Variation of human salivary $O$-glycome. PLoS ONE 11:e0162824

Kraehenbuhl JP, Neutra MR (2000) Epithelial M cells: differentiation and function. Annu Rev Cell Dev Biol 16:301-332

Kreda SM, Davis CW, Rose MC (2012) CFTR, mucins, and mucus obstruction in cystic fibrosis. Cold Spring Harb Perspect Med 2:a009589

Kyo K, Muto T, Nagawa H, Lathrop GM, Nakamura Y (2001) Associations of distinct variants of the intestinal mucin gene MUC3A with ulcerative colitis and Crohn's disease. J Hum Genet 46:5-20

Larsson JM, Karlsson H, Sjovall H, Hansson GC (2009) A complex, but uniform $O$-glycosylation of the human MUC2 mucin from colonic biopsies analyzed by nanoLC/MSn. Glycobiology 19:756-766

Larsson JM, Karlsson H, Crespo JG, Johansson ME, Eklund L, Sjovall H, Hansson GC (2011) Altered $O$-glycosylation profile of MUC2 mucin occurs in active ulcerative colitis and is associated with increased inflammation. Inflamm Bowel Dis 17:2299-2307

Lauc G, Kristic J, Zoldos V (2014) Glycans-the third revolution in evolution. Front Genet 5:145

Ledeen RW, Wu G (2009) Neurobiology meets glycosciences. In: Gabius H-J (ed) The sugar code. Fundamentals of glycosciences. Wiley-VCH, Weinheim, pp 495-516

Lee J, Dubey VK, Somasundaram T, Blaber M (2006) Conversion of type I 4:6 to 3:5 beta-turn types in human acidic fibroblast growth factor: effects upon structure, stability, folding, and mitogenic function. Proteins 62:686-697

Lee DC, Hassan SS, Romero R, Tarca AL, Bhatti G, Gervasi MT, Caruso JA, Stemmer PM, Kim CJ, Hansen LK, Becher N, Uldbjerg N (2011) Protein profiling underscores immunological functions of uterine cervical mucus plug in human pregnancy. $\mathbf{J}$ Proteomics 74:817-828

Leone V, Chang EB, Devkota S (2013) Diet, microbes, and host genetics: the perfect storm in inflammatory bowel diseases. $\mathrm{J}$ Gastroenterol 48:315-321

Lewis AL, Lewis WG (2012) Host sialoglycans and bacterial sialidases: a mucosal perspective. Cell Microbiol 14:1174-1182 
Linden SK, Sutton P, Karlsson NG, Korolik V, McGuckin MA (2008) Mucins in the mucosal barrier to infection. Nat Mucosal Immunol 1:183-197

Liu L, Xu YX, Hirschberg CB (2010) The role of nucleotide sugar transporters in development of eukaryotes. Semin Cell Dev Biol 21:600-608

Lommel M, Strahl S (2009) Protein $O$-mannosylation: conserved from bacteria to humans. Glycobiology 19:816-828

Longman RJ, Poulsom R, Corfield AP, Warren BF, Wright NA, Thomas MG (2006) Alterations in the composition of the supramucosal defense barrier in relation to disease severity of ulcerative colitis. J Histochem Cytochem 54:1335-1348

Lowe JB (1997) Selectin ligands, leukocyte trafficking, and fucosyltransferase genes. Kidney Int 51:1418-1426

Ma J, Hart GW (2014) $O$-GlcNAc profiling: from proteins to proteomes. Clin Proteomics 11:8

Ma F, Wu D, Deng L, Secrest P, Zhao J, Varki N, Lindheim S, Gagneux P (2012) Sialidases on mammalian sperm mediate deciduous sialylation during capacitation. J Biol Chem 287:38073-38079

Malagolini N, Santini D, Chiricolo M, Dall'Olio F (2007) Biosynthesis and expression of the Sda and sialyl Lewis $\times$ antigens in normal and cancer colon. Glycobiology 17:688-697

Mann B, Klussmann E, Vandamme-Feldhaus V, Iwersen M, Hanski ML, Riecken EO, Buhr HJ, Schauer R, Kim YS, Hanski C (1997) Low $O$-acetylation of sialyl- $\mathrm{LE}^{\mathrm{X}}$ contributes to its overexpression in colon carcinoma metastases. Int J Cancer 72:258-264

Manning JC, Romero A, Habermann F, García Caballero G, Kaltner H, Gabius H-J (2017) Lectins: a primer for histochemists and cell biologists. Histochem Cell Biol 147(2). doi:10.1007/ s00418-016-1524-6

Mantelli F, Argüeso P (2008) Functions of ocular surface mucins in health and disease. Curr Opin Allergy Clin Immunol 8:477-483

Marcelo F, Garcia-Martin F, Matsushita T, Sardinha J, Coelho H, Oude-Vrielink A, Koller C, André S, Cabrita EJ, Gabius H-J, Nishimura S-I, Jiménez-Barbero J, Cañada FJ (2014) Delineating binding modes of $\mathrm{Gal} / \mathrm{GalNAc}$ and structural elements of the molecular recognition of tumor-associated mucin glycopeptides by the human macrophage galactose-type lectin. Chem Eur J 20:16147-16155

Marcos NT, Bennett EP, Gomes J, Magalhaes A, Gomes C, David L, Dar I, Jeanneau C, DeFrees S, Krustrup D, Vogel LK, Kure EH, Burchell J, Taylor-Papadimitriou J, Clausen H, Mandel U, Reis CA (2011) ST6GalNAc-I controls expression of sialyl-Tn antigen in gastrointestinal tissues. Front Biosci 3:1443-1455

Marino K, Bones J, Kattla JJ, Rudd PM (2010) A systematic approach to protein glycosylation analysis: a path through the maze. Nat Chem Biol 6:713-723

Marth JD, Grewal PK (2008) Mammalian glycosylation in immunity. Nat Rev Immunol 8:874-887

Mayer S, Raulf M-K, Lepenies B (2017) C-type lectins: their network and roles in immunity/pathogen recognition. Histochem Cell Biol 147(2). doi:10.1007/s00418-016-1523-7

McCauley TC, Kurth BE, Norton EJ, Klotz KL, Westbrook VA, Rao AJ, Herr JC, Diekman AB (2002) Analysis of a human sperm CD52 glycoform in primates: identification of an animal model for immunocontraceptive vaccine development. Biol Reprod 66:1681-1688

McGuckin MA, Linden SK, Sutton P, Florin TH (2011) Mucin dynamics and enteric pathogens. Nat Rev Microbiol 9:265-278

Mengerink KJ, Vacquier VD (2001) Glycobiology of sperm-egg interactions in deuterostomes. Glycobiology 11:37R-43R

Mi Y, Lin A, Fiete D, Steirer L, Baenziger JU (2014) Modulation of mannose and asialoglycoprotein receptor expression determines glycoprotein hormone half-life at critical points in the reproductive cycle. J Biol Chem 289:12157-12167
Miyata S, Sato C, Kitamura S, Toriyama M, Kitajima K (2004) A major flagellum sialoglycoprotein in sea urchin sperm contains a novel polysialic acid, an $\alpha 2,9$-linked poly- $N$-acetylneuraminic acid chain, capped by an $8-O$-sulfated sialic acid residue. Glycobiology 14:827-840

Miyata S, Sato C, Kumita H, Toriyama M, Vacquier VD, Kitajima K (2006) Flagellasialin: a novel sulfated $\alpha 2,9$-linked polysialic acid glycoprotein of sea urchin sperm flagella. Glycobiology 16:1229-1241

Moncla BJ, Chappell CA, Mahal LK, Debo BM, Meyn LA, Hillier SL (2015) Impact of bacterial vaginosis, as assessed by nugent criteria and hormonal status on glycosidases and lectin binding in cervicovaginal lavage samples. PLoS ONE 10:e0127091

Moncla BJ, Chappell CA, Debo BM, Meyn LA (2016) The effects of hormones and vaginal microflora on the glycome of the female genital tract: cervical-vaginal fluid. PLoS ONE 11:e0158687

Morampudi V, Dalwadi U, Bhinder G, Sham HP, Gill SK, Chan J, Bergstrom KS, Huang T, Ma C, Jacobson K, Gibson DL, Vallance BA (2016) The goblet cell-derived mediator RELM- $\beta$ drives spontaneous colitis in Muc2-deficient mice by promoting commensal microbial dysbiosis. Mucosal Immunol 9:1218-1233

Moran AP, Gupta A, Joshi L (2011) Sweet-talk: role of host glycosylation in bacterial pathogenesis of the gastrointestinal tract. Gut 60:1412-1425

Morell AG, Gregoriadis G, Scheinberg IH, Hickman J, Ashwell G (1971) The role of sialic acid in determining the survival of glycoproteins in the circulation. J Biol Chem 246:1461-1467

Moremen KW, Tiemeyer M, Nairn AV (2012) Vertebrate protein glycosylation: diversity, synthesis and function. Nat Rev Mol Cell Biol 13:448-462

Mourao PA (2007) A carbohydrate-based mechanism of species recognition in sea urchin fertilization. Braz J Med Biol Res 40:5-17

Mühlenhoff M, Oltmann-Norden I, Weinhold B, Hildebrandt H, Gerardy-Schahn R (2009) Brain development needs sugar: the role of polysialic acid in controlling NCAM functions. Biol Chem 390:567-574

Murphy PV, André S, Gabius H-J (2013) The third dimension of reading the sugar code by lectins: design of glycoclusters with cyclic scaffolds as tools with the aim to define correlations between spatial presentation and activity. Molecules 18:4026-4053

Myerscough N, Sylvester PA, Warren BF, Biddolph S, Durdey P, Thomas MG, Carlstedt I, Corfield AP (2001) Abnormal subcellular distribution of mature MUC2 and de novo MUC5AC mucins in adenomas of the rectum: immunohistochemical detection using non-VNTR antibodies to MUC2 and MUC5AC peptide. Glycoconj J 18:907-914

Nakagawa H (2009) Analytical aspects: analysis of protein-bound glycans. In: Gabius H-J (ed) The sugar code. Fundamentals of glycosciences. Wiley-VCH, Weinheim, pp 71-83

Nakayama J, Yeh JC, Misra AK, Ito S, Katsuyama T, Fukuda M (1999) Expression cloning of a human $\alpha 1,4-N$-acetylglucosaminyltransferase that forms GlcNAc $\alpha 1 \rightarrow 4 \mathrm{Gal} \beta \rightarrow \mathrm{R}$, a glycan specifically expressed in the gastric gland mucous cell-type mucin. Proc Natl Acad Sci USA 96:8991-8996

Natividad JM, Petit V, Huang X, de Palma G, Jury J, Sanz Y, Philpott D, Garcia Rodenas CL, McCoy KD, Verdu EF (2012) Commensal and probiotic bacteria influence intestinal barrier function and susceptibility to colitis in $\mathrm{Nod}^{-/-}$; Nod2 $2^{-/-}$mice. Inflamm Bowel Dis 18:1434-1446

Neubert P, Strahl S (2016) Protein $O$-mannosylation in the early secretory pathway. Curr Opin Cell Biol 41:100-108

Neuman MG, Nanau RM (2012) Inflammatory bowel disease: role of diet, microbiota, life style. Transl Res 160:29-44 
Newton JL, Jordan N, Pearson J, Williams GV, Allen A, James OF (2000) The adherent gastric antral and duodenal mucus gel layer thins with advancing age in subjects infected with Helicobacter pylori. Gerontology 46:153-157

Nieuw Amerongen AV, Bolscher JGM, Veerman ECI (1995) Salivary mucins: protective functions in relation to their diversity. Glycobiology 5:733-740

Nieuw Amerongen AV, Ligtenberg AJ, Veerman EC (2007) Implications for diagnostics in the biochemistry and physiology of saliva. Ann N Y Acad Sci 1098:1-6

Oftedal OT, Nicol SC, Davies NW, Sekii N, Taufik E, Fukuda K, Saito T, Urashima T (2014) Can an ancestral condition for milk oligosaccharides be determined? Evidence from the Tasmanian echidna (Tachyglossus aculeatus setosus). Glycobiology 24:826-839

Onderdonk AB, Delaney ML, Fichorova RN (2016) The human microbiome during bacterial vaginosis. Clin Microbiol Rev 29:223-238

Ouellette AJ (2011) Paneth cell $\alpha$-defensins in enteric innate immunity. Cell Mol Life Sci 68:2215-2229

Pang PC, Tissot B, Drobnis EZ, Sutovsky P, Morris HR, Clark GF, Dell A (2007) Expression of bisecting type and Lewis $\mathrm{x} /$ Lewis ${ }^{y}$ terminated $\mathrm{N}$-glycans on human sperm. J Biol Chem 282:36593-36602

Pang PC, Chiu PC, Lee CL, Chang LY, Panico M, Morris HR, Haslam SM, Khoo KH, Clark GF, Yeung WS, Dell A (2011) Human sperm binding is mediated by the sialyl-Lewis ${ }^{\mathrm{x}}$ oligosaccharide on the zona pellucida. Science 333:1761-1764

Panin VM, Wells L (2014) Protein $O$-mannosylation in metazoan organisms. Curr Protoc Protein Sci 75:Unit 12.12

Parfrey LW, Walters WA, Lauber CL, Clemente JC, Berg-Lyons D, Teiling C, Kodira C, Mohiuddin M, Brunelle J, Driscoll M, Fierer N, Gilbert JA, Knight R (2014) Communities of microbial eukaryotes in the mammalian gut within the context of environmental eukaryotic diversity. Front Microbiol 5:298

Parry S, Wong NK, Easton RL, Panico M, Haslam SM, Morris HR, Anderson P, Klotz KL, Herr JC, Diekman AB, Dell A (2007) The sperm agglutination antigen-1 (SAGA-1) glycoforms of CD52 are $O$-glycosylated. Glycobiology 17:1120-1126

Patsos G, Corfield A (2009) $O$-Glycosylation: structural diversity and functions. In: Gabius H-J (ed) The sugar code. Fundamentals of glycosciences. Wiley-VCH, Weinheim, pp 111-137

Paulsen F (2008) Functional anatomy and immunological interactions of ocular surface and adnexa. Dev Ophthalmol 41:21-35

Paulsen FP, Berry MS (2006) Mucins and TFF peptides of the tear film and lacrimal apparatus. Prog Histochem Cytochem 41:1-53

Pearson JP, Allen A, Hutton DA (2000) Rheology of mucin. Methods Mol Biol 125:99-109

Pelaseyed T, Bergström JH, Gustafsson JK, Ermund A, Birchenough GM, Schütte A, van der Post S, Svensson F, Rodríguez-Piñeiro AM, Nyström EE, Wising C, Johansson ME, Hansson GC (2014) The mucus and mucins of the goblet cells and enterocytes provide the first defense line of the gastrointestinal tract and interact with the immune system. Immunol Rev 260:8-20

Percec V, Leowanawat P, Sun HJ, Kulikov O, Nusbaum CD, Tran TM, Bertin A, Wilson DA, Peterca M, Zhang S, Kamat NP, Vargo K, Moock D, Johnston ED, Hammer DA, Pochan DJ, Chen Y, Chabre YM, Shiao TC, Bergeron-Brlek M, André S, Roy R, Gabius H-J, Heiney PA (2013) Modular synthesis of amphiphilic Janus glycodendrimers and their self-assembly into glycodendrimersomes and other complex architectures with bioactivity to biomedically relevant lectins. J Am Chem Soc 135:9055-9077

Perez-Vilar J, Randell SH, Boucher RC (2004) C-Mannosylation of MUC5AC and MUC5B cys subdomains. Glycobiology $14: 325-337$
Petrescu SM, Branza-Nichita N, Negroiu G, Petrescu AJ, Dwek RA (2000) Tyrosinase and glycoprotein folding: roles of chaperones that recognize glycans. Biochemistry 39:5229-5237

Pflugfelder SC, Liu Z, Monroy D, Li DQ, Carvajal ME, Price-Schiavi SA, Idris N, Solomon A, Perez A, Carraway KL (2000) Detection of sialomucin complex (MUC4) in human ocular surface epithelium and tear fluid. Invest Ophthalmol Vis Sci 41:1316-1326

Pluta K, McGettigan PA, Reid CJ, Browne JA, Irwin JA, Tharmalingam T, Corfield A, Baird A, Loftus BJ, Evans AC, Carrington SD (2012) Molecular aspects of mucin biosynthesis and mucus formation in the bovine cervix during the periestrous period. Physiol Genomics 44:1165-1178

Png CW, Lindén SK, Gilshenan KS, Zoetendal EG, McSweeney CS, Sly LI, McGuckin MA, Florin TH (2010) Mucolytic bacteria with increased prevalence in IBD mucosa augment in vitro utilization of mucin by other bacteria. Am J Gastroenterol 105:2420-2428

Praissman JL, Wells L (2014) Mammalian $O$-mannosylation pathway: glycan structures, enzymes, and protein substrates. Biochemistry 53:3066-3078

Probert CS, Jayanathi V, Hughes AO, Thompson JR, Wicks ACB, Mayberry JF (1993) Prevalence and family risk of ulcerative colitis and Crohn's disease: an epidemiological study amongst Europeans and South Asians in Leicestershire. Gut 34:1547-1551

Probert CS, Warren BF, Perry T, Mackay EH, Mayberry JF, Corfield AP (1995) South Asian and European colitics show characteristic differences in colonic mucus glycoprotein type and turnover. Gut 36:696-702

Probert CS, Reade S, Ahmed I (2014) Fecal volatile organic compounds: a novel, cheaper method of diagnosing inflammatory bowel disease? Expert Rev Clin Immunol 10:1129-1131

Pullan RD, Thomas GA, Rhodes M, Newcombe RG, Williams GT, Allen A, Rhodes J (1994) Thickness of adherent mucus gel on colonic mucosa in humans and its relevance to colitis. Gut 35:353-359

Rabinovich GA, van Kooyk Y, Cobb BA (2012) Glycobiology of immune responses. Ann N Y Acad Sci 1253:1-15

Reis CA, David L, Correa P, Carneiro F, de Bolos C, Garcia E, Mandel U, Clausen H, Sobrinho-Simoes M (1999) Intestinal metaplasia of human stomach displays distinct patterns of mucin (MUC1, MUC2, MUC5AC, and MUC6) expression. Cancer Res 59:1003-1007

Reunanen J, Kainulainen V, Huuskonen L, Ottman N, Belzer C, Huhtinen H, de Vos WM, Satokari R (2015) Akkermansia muciniphila adheres to enterocytes and strengthens the integrity of the epithelial cell layer. Appl Environ Microbiol 81:3655-3662

Reuter G, Gabius H-J (1999) Eukaryotic glycosylation: whim of nature or multipurpose tool? Cell Mol Life Sci 55:368-422

Revoredo L, Wang S, Bennett EP, Clausen H, Moremen KW, Jarvis DL, Ten Hagen KG, Tabak LA, Gerken TA (2016) Mucin-type $O$-glycosylation is controlled by short- and long-range glycopeptide substrate recognition that varies among members of the polypeptide GalNAc transferase family. Glycobiology 26:360-376

Robbe C, Capon C, Maes E, Rousset M, Zweibaum A, Zanetta JP, Michalski JC (2003) Evidence of regio-specific glycosylation in human intestinal mucins: presence of an acidic gradient along the intestinal tract. J Biol Chem 278:46337-46348

Robbe C, Capon C, Coddeville B, Michalski JC (2004) Structural diversity and specific distribution of $O$-glycans in normal human mucins along the intestinal tract. Biochem J 384:307-316

Robbe C, Paraskeva C, Mollenhauer J, Michalski JC, Sergi C, Corfield A (2005) DMBT1 expression and glycosylation during the 
adenoma-carcinoma sequence in colorectal cancer. Biochem Soc Trans 33:730-732

Robbe-Masselot C, Maes E, Rousset M, Michalski JC, Capon C (2009) Glycosylation of human fetal mucins: a similar repertoire of $O$-glycans along the intestinal tract. Glycoconj $\mathrm{J}$ 26:397-413

Roberton AM, Wiggins R, Horner PJ, Greenwood R, Crowley T, Fernandes A, Berry M, Corfield AP (2005) A novel bacterial mucinase, glycosulfatase, is associated with bacterial vaginosis. $\mathrm{J}$ Clin Microbiol 43:5504-5508

Rodriguez MC, Yegorova S, Pitteloud JP, Chavaroche AE, André S, Ardá A, Minond D, Jiménez-Barbero J, Gabius H-J, Cudic M (2015) Thermodynamic switch in binding of adhesion/ growth regulatory human galectin-3 to tumor-associated TF antigen (CD176) and MUC1 glycopeptides. Biochemistry 54:4462-4474

Rodríguez-Piñeiro AM, Bergstrom JH, Ermund A, Gustafsson JK, Schütte A, Johansson ME, Hansson GC (2013) Studies of mucus in mouse stomach, small intestine, and colon. II. Gastrointestinal mucus proteome reveals Muc2 and Muc5ac accompanied by a set of core proteins. Am J Physiol Gastrointest Liver Physiol 305:G348-G356

Rose MC, Voynow JA (2006) Respiratory tract mucin genes and mucin glycoproteins in health and disease. Physiol Rev $86: 245-278$

Roth J (1993) Cellular sialoglycoconjugates: a histochemical perspective. Histochem J 25:687-710

Roth J (1996) Protein glycosylation in the endoplasmic reticulum and the Golgi apparatus and cell type-specificity of cell surface glycoconjugate expression: analysis by the protein A-gold and lectin-gold techniques. Histochem Cell Biol 106:79-92

Roth J (2002) Protein $N$-glycosylation along the secretory pathway: relationship to organelle topography and function, protein quality control, and cell interactions. Chem Rev 102:285-303

Roth J (2011) Lectins for histochemical demonstration of glycans. Histochem Cell Biol 136:117-130

Roth J, Zuber C (2017) Quality control of glycoprotein folding and ERAD: the role of $N$-glycan handling, EDEM1 and OS-9. Histochem Cell Biol 147(2). doi:10.1007/s00418-016-1513-9

Roth J, Wang Y, Eckhardt AE, Hill RL (1994) Subcellular localization of the UDP- $N$-acetyl-D-galactosamine: polypeptide $N$-acetylgalactosaminyltransferase-mediated $O$-glycosylation reaction in the submaxillary gland. Proc Natl Acad Sci USA 91:8935-8939

Round AN, McMaster TJ, Miles MJ, Corfield AP, Berry M (2007) The isolated MUC5AC gene product from human ocular mucin displays intramolecular conformational heterogeneity. Glycobiology 17:578-585

Rousseau K, Kirkham S, McKane S, Newton R, Clegg P, Thornton DJ (2007) Muc5b and Muc5ac are the major oligomeric mucins in equine airway mucus. Am J Physiol Lung Cell Mol Physiol 292:L1396-L1404

Rousseau K, Kirkham S, Johnson L, Fitzpatrick B, Howard M, Adams EJ, Rogers DF, Knight D, Clegg P, Thornton DJ (2008) Proteomic analysis of polymeric salivary mucins: no evidence for MUC19 in human saliva. Biochem J 413:545-552

Roy R, Murphy PV, Gabius H-J (2016) Multivalent carbohydrate-lectin interactions: how synthetic chemistry enables insights into nanometric recognition. Molecules 21:629

Roy R, Cao Y, Kaltner H, Kottari N, Shiao TC, Belkhadem K, André S, Manning JC, Murphy PV, Gabius H-J (2017) Teaming up synthetic chemistry and histochemistry for activity screening in galectin-directed inhibitor design. Histochem Cell Biol 147(2). doi:10.1007/s00418-016-1525-5

Royle L, Roos A, Harvey DJ, Wormald MR, van Gijlswijk-Janssen D, el Redwan RM, Wilson IA, Daha MR, Dwek RA, Rudd PM (2003) Secretory IgA $N$ - and $O$-glycans provide a link between the innate and adaptive immune systems. J Biol Chem 278:20140-20153

Royle L, Matthews E, Corfield A, Berry M, Rudd PM, Dwek RA, Carrington SD (2008) Glycan structures of ocular surface mucins in man, rabbit and dog display species differences. Glycoconj J 25:763-773

Rudd PM, Wormald MR, Dwek RA (2004) Sugar-mediated ligandreceptor interactions in the immune system. Trends Biotechnol 22:524-530

Rutishauser U (2008) Polysialic acid in the plasticity of the developing and adult vertebrate nervous system. Nat Rev Neurosci 9:26-35

Saludes JP, Natarajan A, DeNardo SJ, Gervay-Hague J (2010) The remarkable stability of chimeric, sialic acid-derived $\alpha / \delta$-peptides in human blood plasma. Chem Biol Drug Des 75:455-460

Salzman NH, Bevins CL (2013) Dysbiosis: a consequence of Paneth cell dysfunction. Semin Immunol 25:334-341

Schachter H, Brockhausen I (1992) The biosynthesis of serine (threonine)- $\mathrm{N}$-acetylgalactosamine-linked carbohydrate moieties. In: Allen HJ, Kisailus EC (eds) Glycoconjugates. Marcel Dekker, New York, pp 263-332

Schegg B, Hulsmeier AJ, Rutschmann C, Maag C, Hennet T (2009) Core glycosylation of collagen is initiated by two $\beta(1-O)$ galactosyltransferases. Mol Cell Biol 29:943-952

Schnaar RL, Gerardy-Schahn R, Hildebrandt H (2014) Sialic acids in the brain: gangliosides and polysialic acid in nervous system development, stability, disease, and regeneration. Physiol Rev 94:461-518

Seppala M, Taylor RN, Koistinen H, Koistinen R, Milgrom E (2002) Glycodelin: a major lipocalin protein of the reproductive axis with diverse actions in cell recognition and differentiation. Endocr Rev 23:401-430

Serafini-Cessi F, Monti A, Cavallone D (2005) N-Glycans carried by Tamm-Horsfall glycoprotein have a crucial role in the defense against urinary tract diseases. Glycoconj J 22:383-394

Shams-Eldin H, Debierre-Grockiego F, Schwarz RT (2009) Glycosylphosphatidylinositol anchors: structure, biosynthesis and functions. In: Gabius H-J (ed) The sugar code. Fundamentals of glycosciences. Wiley-VCH, Weinheim, pp 155-173

Shanahan F, Collins SM (2010) Pharmabiotic manipulation of the microbiota in gastrointestinal disorders, from rationale to reality. Gastroenterol Clin North Am 39:721-726

Shaoul R, Okada Y, Cutz E, Marcon MA (2004) Colonic expression of MUC2, MUC5AC, and TFF1 in inflammatory bowel disease in children. J Pediatr Gastroenterol Nutr 38:488-493

Sheehan JK, Kirkham S, Howard M, Woodman P, Kutay S, Brazeau C, Buckley J, Thornton DJ (2004) Identification of molecular intermediates in the assembly pathway of the MUC5AC mucin. J Biol Chem 279:15698-15705

Shen Y, Kohla G, Lrhorfi AL, Sipos B, Kalthoff H, Gerwig GJ, Kamerling JP, Schauer R, Tiralongo J (2004) $O$-Acetylation and de- $O$-acetylation of sialic acids in human colorectal carcinoma. Eur J Biochem 271:281-290

Sheng YH, Hasnain SZ, Florin TH, McGuckin MA (2012) Mucins in inflammatory bowel diseases and colorectal cancer. J Gastroenterol Hepatol 27:28-38

Shoemark DK, Allen SJ (2015) The microbiome and disease: reviewing the links between the oral microbiome, aging, and Alzheimer's disease. J Alzheimers Dis 43:725-738

Silva E, Kadirvel G, Jiang R, Bovin N, Miller D (2014) Multiple proteins from ejaculated and epididymal porcine spermatozoa bind glycan motifs found in the oviduct. Andrology 2:763-771

Simon P, Bäumner S, Busch O, Röhrich R, Kaese M, Richterich P, Wehrend A, Müller K, Gerardy-Schahn R, Mühlenhoff M, Geyer H, Geyer R, Middendorff R, Galuska SP (2013) 
Polysialic acid is present in mammalian semen as a posttranslational modification of the neural cell adhesion molecule NCAM and the polysialyltransferase ST8SiaII. J Biol Chem 288:18825-18833

Solís D, Bovin NV, Davis AP, Jiménez-Barbero J, Romero A, Roy R, Smetana K Jr, Gabius H-J (2015) A guide into glycosciences: how chemistry, biochemistry and biology cooperate to crack the sugar code. Biochim Biophys Acta 1850:186-235

Springer SA, Gagneux P (2016) Glycomics: revealing the dynamic ecology and evolution of sugar molecules. J Proteomics 135:90-100

Stechly L, Morelle W, Dessein AF, André S, Grard G, Trinel D, Dejonghe MJ, Leteurtre E, Drobecq H, Trugnan G, Gabius H-J, Huet G (2009) Galectin-4-regulated delivery of glycoproteins to the brush border membrane of enterocyte-like cells. Traffic 10:438-450

Stonebraker JR, Wagner D, Lefensty RW, Burns K, Gendler SJ, Bergelson JM, Boucher RC, O'Neal WK, Pickles RJ (2004) Glycocalyx restricts adenoviral vector access to apical receptors expressed on respiratory epithelium in vitro and in vivo: role for tethered mucins as barriers to lumenal infection. J Virol 78:13755-13768

Strugala V, Allen A, Dettmar PW, Pearson JP (2003) Colonic mucin: methods of measuring mucus thickness. Proc Nutr Soc 62:237-243

Sylvester PA, Myerscough N, Warren BF, Carlstedt I, Corfield AP, Durdey P, Thomas MG (2001) Differential expression of the chromosome 11 mucin genes in colorectal cancer. J Pathol 195:327-335

Tabak LA (2006) In defense of the oral cavity: the protective role of the salivary secretions. Pediatr Dent 28:110-117 (discussion 192-118)

Tabak LA (2010) The role of mucin-type $O$-glycans in eukaryotic development. Semin Cell Dev Biol 21:616-621

Takeuchi H, Haltiwanger RS (2014) Significance of glycosylation in Notch signaling. Biochem Biophys Res Commun 453:235-242

Takeuchi H, Kantharia J, Sethi MK, Bakker H, Haltiwanger RS (2012) Site-specific $O$-glucosylation of the epidermal growth factor-like (EGF) repeats of notch: efficiency of glycosylation is affected by proper folding and amino acid sequence of individual EGF repeats. J Biol Chem 287:33934-33944

Tan FY, Tang CM, Exley RM (2015) Sugar coating: bacterial protein glycosylation and host-microbe interactions. Trends Biochem Sci 40:342-350

Tecle E, Gagneux P (2015) Sugar-coated sperm: unraveling the functions of the mammalian sperm glycocalyx. Mol Reprod Dev $82: 635-650$

Theodoratou E, Campbell H, Ventham NT, Kolarich D, Pucic-Bakovic M, Zoldos V, Fernandes D, Pemberton IK, Rudan I, Kennedy NA, Wuhrer M, Nimmo E, Annese V, McGovern DP, Satsangi J, Lauc G (2014) The role of glycosylation in IBD. Nat Rev Gastroenterol Hepatol 11:588-600

Thomsson KA, Holmén-Larsson JM, Angström J, Johansson ME, Xia L, Hansson GC (2012) Detailed $O$-glycomics of the Muc2 mucin from colon of wild-type, core 1- and core 3-transferasedeficient mice highlights differences compared with human MUC2. Glycobiology 22:1128-1139

Thornton DJ, Howard M, Khan N, Sheehan JK (1997) Identification of two glycoforms of the MUC5B mucin in human respiratory mucus-evidence for a cysteine-rich sequence repeated within the molecule. J Biol Chem 272:9561-9566

Thornton DJ, Khan N, Mehrotra R, Howard M, Veerman E, Packer NH, Sheehan JK (1999) Salivary mucin MG1 is comprised almost entirely of different glycosylated forms of the MUC5B gene product. Glycobiology 9:293-302
Thornton DJ, Khan N, Sheehan JK (2000) Separation and identification of mucins and their glycoforms. Methods Mol Biol 125:77-85

Thornton DJ, Rousseau K, McGuckin MA (2008) Structure and function of the polymeric mucins in airways mucus. Annu Rev Physiol 70:459-486

Tian E, Hagen KG (2007) $O$-Linked glycan expression during Drosophila development. Glycobiology 17:820-827

Tollner TL, Bevins CL, Cherr GN (2012) Multifunctional glycoprotein DEFB126: a curious story of defensin-clad spermatozoa. Nat Rev Urol 9:365-375

Tran DT, Ten Hagen KG (2013) Mucin-type $O$-glycosylation during development. J Biol Chem 288:6921-6929

Tringali C, Lupo B, Silvestri I, Papini N, Anastasia L, Tettamanti G, Venerando B (2012) The plasma membrane sialidase NEU3 regulates the malignancy of renal carcinoma cells by controlling $\beta 1$ integrin internalization and recycling. J Biol Chem 287:42835-42845

Tytgat KMAJ, Büller HA, Opdam FJM, Kim YS, Einerhand AWC, Dekker J (1994) Biosynthesis of human colonic mucin: Muc2 is the predominant secretory mucin. Gastroenterology 107:1352-1363

Unverzagt C, André S, Seifert J, Kojima S, Fink C, Srikrishna G, Freeze H, Kayser K, Gabius H-J (2002) Structure-activity profiles of complex biantennary glycans with core fucosylation and with/without additional $\alpha 2,3 / \alpha 2,6$ sialylation: synthesis of neoglycoproteins and their properties in lectin assays, cell binding, and organ uptake. J Med Chem 45:478-491

Van Klinken BJW, De Bolos C, Büller HA, Dekker J, Einerhand AWC (1997) Biosynthesis of mucins (MUC2-6) along the longitudinal axis of the gastrointestinal tract. Am J Physiol 273:G296-G302

Varki A (2011) Since there are PAMPs and DAMPs, there must be SAMPs? Glycan "self-associated molecular patterns" dampen innate immunity, but pathogens can mimic them. Glycobiology $21: 1121-1124$

Varki A, Lowe JB (2009) Biological roles of glycans. In: Varki A, Cummings RD, Esko JD et al (eds) Essentials of glycobiology. Cold Spring Harbor Laboratory Press, New York, pp 75-88

Veerman EC, Van Den Keijbus PA, Nazmi K, Vos W, Van Der Wal JE, Bloemena E, Bolscher JG, Amerongen AV (2003) Distinct localization of MUC5B glycoforms in the human salivary glands. Glycobiology 13:363-366

Velasco S, Díez-Revuelta N, Hernández-Iglesias T, Kaltner H, André S, Gabius H-J, Abad-Rodríguez J (2013) Neuronal galectin-4 is required for axon growth and for the organization of axonal membrane L1 delivery and clustering. J Neurochem 125:49-62

Velásquez JG, Canovas S, Barajas P, Marcos J, Jiménez-Movilla M, Gallego RG, Ballesta J, Avilés M, Coy P (2007) Role of sialic acid in bovine sperm-zona pellucida binding. Mol Reprod Dev 74:617-628

Velcich A, Yang W, Heyer J, Fragale A, Nicholas C, Viani S, Kucherlapati R, Lipkin M, Yang K, Augenlicht L (2002) Colorectal cancer in mice genetically deficient in the mucin Muc2. Science 295:1726-1729

Verdugo P (2012) Supramolecular dynamics of mucus. Cold Spring Harb Perspect Med 2:a009597

Vester-Christensen MB, Halim A, Joshi HJ, Steentoft C, Bennett EP, Levery SB, Vakhrushev SY, Clausen H (2013) Mining the $O$-mannose glycoproteome reveals cadherins as major $O$-mannosylated glycoproteins. Proc Natl Acad Sci USA 110:21018-21023

Vieten D, Corfield A, Carroll D, Ramani P, Spicer R (2005) Impaired mucosal regeneration in neonatal necrotising enterocolitis. Pediatr Surg Int 21:153-160

Vinall LE, Fowler JC, Jones AL, Kirkbride HJ, de Bolos C, Laine A, Porchet N, Gum JR, Kim YS, Moss FM, Mitchell DM, Swallow 
DM (2000) Polymorphism of human mucin genes in chest disease. Possible significance of muc2. Am J Respir Cell Mol Biol 23:678-686

Voynow JA, Gendler SJ, Rose MC (2006) Regulation of mucin genes in chronic inflammatory airway diseases. Am J Respir Cell Mol Biol 34:661-665

Wagner P, Roth J (1985) Occurrence and distribution of sialic acid residues indeveloping rat glomerulus: investigations with the Limax flavus and wheat germagglutinin. Eur J Cell Biol 47:259-269

Wang ML, Shin ME, Knight PA, Artis D, Silberg DG, Suh E, Wu GD (2005) Regulation of RELM/FIZZ isoform expression by $\mathrm{Cdx} 2$ in response to innate and adaptive immune stimulation in the intestine. Am J Physiol Gastrointest Liver Physiol 288:G1074-G1083

Wang L, Koppolu S, Chappell C, Moncla BJ, Hillier SL, Mahal LK (2015) Studying the effects of reproductive hormones and bacterial vaginosis on the glycome of lavage samples from the cervicovaginal cavity. PLoS ONE 10:e0127021

Warren BF (1993) Review in depth-the histopathology of mucins. Eur J Gastroenterol Hepatol 5:200-204

Warson C, Van De Bovenkamp JH, Korteland-Van Male AM, Buller HA, Einerh AW, Ectors NL, Dekker J (2002) Barrett's esophagus is characterized by expression of gastric-type mucins (MUC5AC, MUC6) and TFF peptides (TFF1 and TFF2), but the risk of carcinoma development may be indicated by the intestinal-type mucin, MUC2. Hum Pathol 33:660-668

Weinhold B, Sellmeier M, Schaper W, Blume L, Philippens B, Kats E, Bernard U, Galuska SP, Geyer H, Geyer R, Worthmann K, Schiffer M, Groos S, Gerardy-Schahn R, Munster-Kuhnel AK (2012) Deficits in sialylation impair podocyte maturation. J Am Soc Nephrol 23:1319-1328

Wells I, Hart GW, Athens Guidelines for the Publication of Glycomics Data (2013) Glycomics: building upon proteomics to advance glycosciences. Mol Cell Proteomics 12:833-835

Wiggins R, Crowley T, Horner PJ, Soothill PW, Millar MR, Corfield AP (2000) Use of 5-bromo-4-chloro-3-indolyl- $\alpha$-D- $N$ acetylneuraminic acid in a novel spot test to identify sialidase activity in vaginal swabs from women with bacterial vaginosis. J Clin Microbiol 38:3096-3097

Wiggins R, Hicks SJ, Soothill PW, Millar MR, Corfield AP (2001) Mucinases and sialidases: their role in the pathogenesis of sexually transmitted infections in the female genital tract. Sex Transm Infect 77:402-408

Williams SJ, Wreschner DH, Tran M, Eyre HJ, Sutherl GR, McGuckin MA (2001) Muc13, a novel human cell surface mucin expressed by epithelial and hemopoietic cells. J Biol Chem 276:18327-18336

Wilson IB (2002) Glycosylation of proteins in plants and invertebrates. Curr Opin Struct Biol 12:569-577

Wilson IBH, Paschinger K, Rendic D (2009) Glycosylation of model and 'lower' organisms. In: Gabius H-J (ed) The sugar code. Fundamentals of glycosciences. Wiley-VCH, Weinheim, pp 139-154

Winterburn PJ, Phelps CF (1972) The significance of glycosylated proteins. Nature 236:147-151

Woods EC, Yee NA, Shen J, Bertozzi CR (2015) Glycocalyx engineering with a recycling glycopolymer that increases cell survival in vivo. Angew Chem Int Ed 54:15782-15788

Wright NA (2001) Interaction of trefoil family factors with mucins: clues to their mechanism of action? Gut 48:293-294
Xiao X, Wang L, Wei P, Chi Y, Li D, Wang Q, Ni S, Tan C, Sheng W, Sun M, Zhou X, Du X (2013) Role of MUC20 overexpression as a predictor of recurrence and poor outcome in colorectal cancer. J Transl Med 11:151

$\mathrm{Xu} \mathrm{C}, \mathrm{Ng}$ DT (2015) $O$-Mannosylation: the other glycan player of ER quality control. Semin Cell Dev Biol 41:129-134

Xu C, Wang S, Thibault G, Ng DT (2013) Futile protein folding cycles in the ER are terminated by the unfolded protein $O$-mannosylation pathway. Science 340:978-981

Yaji S, Manya H, Nakagawa N, Takematsu H, Endo T, Kannagi R, Yoshihara T, Asano M, Oka S (2015) Major glycan structure underlying expression of the Lewis ${ }^{X}$ epitope in the developing brain is $O$-mannose-linked glycans on phosphacan/RPTP $\beta$. Glycobiology 25:376-385

Yeung WS, Lee KF, Koistinen R, Koistinen H, Seppala M, Ho PC, Chiu PC (2006) Roles of glycodelin in modulating sperm function. Mol Cell Endocrinol 250:149-156

Yogalingam G, Bonten EJ, van de Vlekkert D, Hu H, Moshiach S, Connell SA, d'Azzo A (2008) Neuraminidase 1 is a negative regulator of lysosomal exocytosis. Dev Cell 15:74-86

Young RH, Clement PB (2000) Endocervicosis involving the uterine cervix: a report of four cases of a benign process that may be confused with deeply invasive endocervical adenocarcinoma. Int J Gynecol Pathol 19:322-328

Yu RK, Yanagisawa M (2006) Glycobiology of neural stem cells. CNS Neurol Disord Drug Targets 5:415-423

Yudin AI, Tollner TL, Treece CA, Kays R, Cherr GN, Overstreet JW, Bevins CL (2008) $\beta$-Defensin 22 is a major component of the mouse sperm glycocalyx. Reproduction 136:753-765

Yurewicz EC, Matsuura F, Moghissi KS (1987) Structural studies of sialylated oligosaccharides of human midcycle cervical mucin. J Biol Chem 262:4733-4739

Zhang S, Moussodia R-O, Vértesy S, André S, Klein ML, Gabius H-J, Percec V (2015a) Unraveling functional significance of natural variations of a human galectin by glycodendrimersomes with programmable glycan surface. Proc Natl Acad Sci USA 112:5585-5590

Zhang S, Moussodia R-O, Murzeau C, Sun HJ, Klein ML, Vértesy S, André S, Roy R, Gabius H-J, Percec V (2015b) Dissecting molecular aspects of cell interactions using glycodendrimersomes with programmable glycan presentation and engineered human lectins. Angew Chem Int Ed 54:4036-4040

Zhou WB, Zhou CF (1996) Role of neural cell adhesion molecule, polysialic acid on the neuronal development, regeneration. Sheng Li Ke Xue Jin Zhan 27:118-122

Zhu-Mauldin X, Marsh SA, Zou L, Marchase RB, Chatham JC (2012) Modification of STIM1 by $O$-linked $N$-acetylglucosamine $(O$-Glc $N A c)$ attenuates store-operated calcium entry in neonatal cardiomyocytes. J Biol Chem 287:39094-39106

Zimmerman RL, Fogt F, Goonewardene S (2000) Diagnostic value of a second generation CA 15-3 antibody to detect adenocarcinoma in body cavity effusions. Cancer 90:230-234

Zuber C, Roth J (1990) The relationship of polysialic acid and the neural cell adhesion molecule N-CAM in Wilms tumor and their subcellular distributions. Eur J Cell Biol 51:313-321

Zuber C, Roth J (2009) N-Glycosylation. In: Gabius H-J (ed) The sugar code. Fundamentals of glycosciences. Wiley-VCH, Weinheim, pp 87-110 